EPISTEMOLOGÍA Y PSICOANÁLISIS 



\section{Bachelard o el complejo de Prometeo}

Feu ou lumière, travail ou intelligence, voilà les deux pôles entre lesquels se développe

l'immense champ du prométhéisme. (BACHELARD, Fragments d'une poétique du feu 30)

Se puede decir, esquemáticamente, que Bachelard pasó de la meditación sobre la racionalidad de la física contemporánea a la poesía y que permaneciendo filósofo elaboró paralelamente una filosofía de las ciencias y una verdadera poética de indiscutibles huellas en la "nueva crítica" (Poulet, Rousset, Maryvonne Meuraud). “iAh, cómo se instruirían los filósofos si consintieran en leer a los poetas!”. Es una de las múltiples expresiones para justificar su pasión por la poesía, concebida hacia el final de su vida como un "asombro precisamente al nivel de la palabra, que se produce en la palabra y por la palabra”. Por otra parte, la división de dos vidas, la diurna para quien sigue de cerca el racionalismo

1 Publicado en Suma Cultural: Revista de cultura contemporánea. No. 4, septiembre de 2001, pp. 1-77. 
de la actividad científica y la nocturna para quien se ocupa de la imaginación poética bien podría conducirnos a la búsqueda de esa "secreta pasión" que une una vida con otra, retomando la expresión de Jean Lescure. Pero lo que es bien claro ante una obra tan polifacética y fecunda es la idea de que tanto la ciencia como la imaginación tienen por finalidad común introducir la novedad en el pensamiento en un esfuerzo continuo de creación.

En cuanto a la epistemología o teoría del conocimiento científico, el punto de partida lo constituye la conciencia de la novedad introducida por la relatividad como uno de los caracteres más evidentes. Progreso del pensamiento, extraordinaria construcción, y creación de experiencia son en efecto, a la vez, la gran vía de acceso a una descripción de la relatividad y de lo que más tarde será su concepción y explicación de la dinámica de la ciencia. La novedad relativista se presenta en contravía con los datos del empirismo y en ruptura con un cuerpo de experiencias anteriores. Ahora bien, lo que caracteriza a la ciencia en relación con otras actividades humanas es precisamente el progreso. La ciencia puede progresar solamente a través de las rupturas (el sistema de Einstein en ruptura con el de Newton), porque lo que constituye al espíritu científico es la constante renovación, la permanente problematización, el recomienzo. Es así como Bachelard va a definir la ciencia como una escuela permanente y simultáneamente va a reclamar reformas pedagógicas que lleven la marca de una tajante separación entre curiosidad natural y curiosidad científica y rechacen la experiencia inmediata en cuanto esta se puede convertir en un estorbo para la experiencia científica. Al proponer una epistemología que se desarrolle a partir de cada ciencia en particular, concretamente la física y la química, se rompe con toda teoría general del conocimiento y con el esquema tradicional de un método científico general.

Hay que reconocer, por otra parte, que si les tributa a la ciencia y a la expresión literaria el mismo género de admiración es porque las dos presentan una característica común, en el sentido de que son inconcebibles sin la creatividad, valor supremo que Bachelard le exige a la ciencia. Cabe decir, además, que para él la literatura tiene por función la creación de nuevas imágenes y que el signo de la creación artística o de "la potencia creadora de la imaginación" lo constituye 
precisamente la novedad. Valga recordar aquí la analogía que establece entre la creación artística y la procreación de un hijo. La autonomía que constantemente le señala a la expresión literaria y a la poesía no es otra cosa que un intento por liberar la imaginación o, lo que es lo mismo, oponerse a todo lo que la determina.

Con el título Bachelard o el complejo de Prometeo (síntesis de todas las tendencias que nos impulsan a saber) hemos querido caracterizar a nuestro autor mismo en un esfuerzo por aproximarnos a sus dos universos, el epistemológico y el poético; porque es bien visible su interés tan especial por las creaciones culturales de la humanidad: la ciencia, los mitos, la producción literaria, la poesía de los románticos alemanes y del surrealismo, la pintura. Viendo cómo hace entrar en escena uno tras otro a Jung con José Eustasio Rivera, a Shelley con Nietzsche, a Pinheiro dos Santos y el ritmoanálisis con el psicoanálisis de Freud, nada tiene de sorprendente esta plegaria dirigida en las mañanas al dios de la lectura: "Nuestra hambre cotidiana dánosla hoy" y que como buen ebanista del lenguaje y de la imaginación activa se pregunte en la Poética de la ensoñación: “¿Acaso, allá arriba en el cielo, el paraíso no es una inmensa biblioteca?” (8).

Algunas precisiones sobre el sentido y los límites que nos hemos asignado con el presente trabajo se hacen necesarias. En primer lugar, la pregunta por qué y para qué acude al psicoanálisis un filósofo de la ciencia que ha tomado conciencia del desfase entre la filosofía de su tiempo y el desarrollo científico, nos revela una profunda preocupación pedagógica. Porque llama la atención que en 1938 el término "psicoanálisis" aparezca en el título de dos obras: La formación del espíritu científico. Contribución a un psicoanálisis del fuego, después de una amplia reflexión sobre las llamadas ciencias exactas de una amplia reflexión sobre las llamadas ciencias exactas, la relatividad (La valeur inductive de la relativité, 1929), la microfísica (Npumène et microphysique, 1931-2), la química moderna (Le pluralisme cohérent de la chimie moderne, 1932), dos estudios sobre el tiempo (La Intuición del Instante, 1935; La dialéctica de la duración, 1936) y uno sobre la experiencia del espacio en la física contemporánea (1937). Una clave para esta interpretación la constituye la afirmación expresada en el último de los escritos sobre la física contemporánea: "las imágenes, como las 
lenguas cocinadas por Esopo, son a la vez buenas y malas, indispensables y dañinas, hay que saberlas usar con medida cuando son buenas y desembarazarse de ellas cuando se vuelven inútiles" (La actividad racionalista de la física contemporánea 19).

En segundo lugar, Bachelard le dedicó un estudio a Lautréamont en 1939, lo que significó la aparición de otra vertiente en su obra, las preocupaciones por la imaginación, y concretamente, la imaginación literaria. El hecho de que la imaginación sea concebida como la función de lo irreal plantea la necesidad de hacer explícita la relación el surrealismo y el vínculo con poetas que escribieron sobre la imaginación y las relaciones entre lo imaginario y lo real, más allá de las simples simetrías establecidas entre superracionalismo y surrealismo, entre racionalismo abierto o surrealismo y de las referencias a Tristán Tzara como a primera vista aparecen en sus escritos.

La fe en los poderes de la imaginación, la insistencia en el onirismo activo de la ensoñación y del sueño nocturno, así como un interés común por la actitud del alquimista y del poeta, son elementos suficientes que impulsan a plantear su relación con el surrealismo. Una vez que se ha declarado el vínculo que establece entre la imagen y la palabra, las creaciones verbales y la imaginación, se hace posible establecer su aproximación al surrealismo como creación de un mundo literario en el que se supera el empleo corriente del lenguaje o, como lo expresa Bretón, se emancipan las palabras devolviéndoles toda su fuerza. Finalmente es necesario distinguir cuidadosamente, con Bachelard mismo, entre imagen y concepto, imagen y metáfora, símbolo y lenguaje en la expresión poética y el sistema de símbolos de la imaginación.

\section{La epistemología neorracionalista}

Vemos pues, que todas las nociones por las cuales suele el vulgo explicar la naturaleza son solo modos de imaginación y no indican la naturaleza de cosa alguna, sino la contextura de la imaginación. (Spinoza, Ética demostrada 8)

Cuando Vincent Descombres en Lo mismo y lo otro hace el balance de cuarenta y cinco años de filosofía francesa no vacila en destacar, 
en el contexto de las páginas consagradas a Foucault, como una de las tendencias más tradicionales de la epistemología aquella que se ha orientado por la formación de los conceptos de una disciplina, sus variaciones y sus obstáculos en el tiempo. En esa tradición instaurada por Bachelard y Canguilhem (La formación del concepto de reflejo en los siglos XVII y XVIII) se inscriben los trabajos de Alexandre Koyré, con nociones tomadas en préstamo ("mutación intelectual”, "ruptura”) para explicar el nacimiento de la ciencia clásica en sus Estudios galileanos y Estudios de historia del pensamiento científico. De otra parte, en la epistemología y la historia de las ciencias, es bien transparente la presencia de Bachelard en Foucault, Althusser, Fichant y Pêcheux o para retomar la expresión de Vadée "la influencia esencialmente ideológica en el seno del pensamiento francés”.

Es preciso recordar ante todo que Gaston Bachelard (1884-1962), el filósofo, el científico y el poeta no están desligados. El ambiente cultural en el que se perfila su itinerario es bien polifacético y de hondas repercusiones a lo largo de sus escritos:

a. Los artistas contemporáneos: Chagall, Marcoussis, Flocon, Waroquier, Simon Segal.

b. Lautréamont y los poetas surrealistas.

c. La filosofía: Bergson, León Brunschvicg, Meyerson, la fenomenología.

d. La psicología y el psicoanálisis: Janet, Minkowski, Carl Jung.

Su obra se presenta como la conjunción de dos vertientes: por una parte, la reflexión sobre la actividad científica y por otra, la filosofía de la creación artística a la que están íntimamente ligadas las preocupaciones por la imaginación poética, la ensoñación, las imágenes e inclusive la práctica de la poesía misma como lo sugiere la lectura de La llama de una vela².

2 "La llama es un mundo para el solitario". "La llama es una verticalidad habitada". "Uno se duerme ante el fuego, pero no ante la llama de una vela". “'Morir por amor, en el amor, como mariposa en la llama no es acaso realizar la síntesis entre Eros y Thanatos?". Desde una teoría de la imagen-frase en la que Bachelard sugiere ligar 
El intento de superación de la vieja antinomia entre poesía y ciencia es un componente importante en toda su obra, ya que a la vez permite comprender afirmaciones como "la ciencia es la estética de la inteligencia”, "la ciencia se forma más bien sobre una ensoñación que sobre una experiencia". Es el romanticismo de la inteligencia, como la califica Hyppolite, pero que pronto será opacado por una clara separación entre las condiciones de la ensoñación y las condiciones del pensamiento.

En los dos frentes explorados, el científico y el literario, entrevemos la presencia del psicoanálisis de Jung y más exactamente su teoría de los arquetipos y el papel de los símbolos en la vida inconsciente. El hombre es un drama de símbolos, declara en La tierra y las ensoñaciones del reposo y por eso el principio subyacente a las reflexiones sobre la alquimia y la imaginación no es otro que las imágenes son sublimaciones de los arquetipos. Sin embargo, en la búsqueda de factores que intervienen en las representaciones sobre el fuego (Psicoanálisis del fuego) se pone en evidencia una encrucijada entre el espíritu poético y el espíritu científico, lo cual plantea la necesidad de un método para el análisis de la formación del pensamiento científico: las trabas que se le presenta en el momento mismo de conocer, los obstáculos, la afectividad de las convicciones y la acción de valores inconscientes. Es el psicoanálisis del conocimiento objetivo, es decir, la revelación de obstáculos epistemológicos, de nociones íntimas, de intuiciones e imágenes, indispensable para liberar al pensamiento racional.

Desde esta perspectiva, una doctrina como la de los cuatro elementos, tan central en los diversos sistemas filosóficos del pensamiento griego y aun en el siglo XVIII con Priestley, está construida según esta forma de psicoanálisis, sobre arquetipos del inconsciente o representaciones colectivas y debe ser examinada a la luz de la premisa de que la actividad científica implica, por lo tanto, el abandono de las convicciones y las imágenes personales. Resulta bien significativo,

directamente imágenes-pensamiento-frase, Jean Lescure nos habla de sentencias poéticas y del poeta gnómico. De ahí el Pequeño compendio de poemas gnómicos elaborado en Un été avec Bachelard (166-170). Mencionamos algunos: "Adán se encontró con Eva al salir de un sueño: por ello la mujer es tan hermosa", "En Brujas todo espejo es un agua dormida", "El lago es un gran ojo tranquilo". 
por ejemplo, que en la representación platónica de la tierra mediante la figura geométrica limitada por seis cuadrados, más allá de una justificación racional sea necesario encontrar elementos propios de una simbología inconsciente en la cual el cuadrado estaría representando la maternidad de la tierra. En estas condiciones no sorprende la variedad de complejos que un psicoanálisis del conocimiento científico puede explorar. Psicoanálisis que desde ahora podemos precisar como material $^{3}$, por cuanto versa sobre objetos, la materia, y que permite dar cuenta de fenómenos como la invención del fuego por frotación, especie de inscripción de los movimientos del amor.

El complejo de Prometeo o complejo de la vida intelectual sintetiza todas las tendencias que nos impulsan a saber; el complejo de Harpagon es el deseo de poseer y se identifica con la avaricia; el complejo de Empédocles es la unión del amor y del respeto por el fuego. Estos y otros complejos (de Medusa, de Atlas, de Ofelia, de Jonás, de agresividad en el poeta de los Cantos de Maldoror) son elaborados desde la perspectiva de un psicoanálisis del cogito científico y sobre todo en relación con la obra literaria donde constituyen una especie de topología psíquica.

\section{Teoría del conocimiento científico}

La verdad es hija de la discusión y no de la simpatía. (BACHELARD, La filosofía del no 111)

Con la aparición de la relatividad y las mecánicas (relativista, cuántica, ondulatoria) Bachelard anuncia el advenimiento del "nuevo espíritu científico", último estadio de la ciencia dentro de su controvertida periodización ${ }^{4}$, al que necesariamente debe corresponderle una nueva

3 Psicoanálisis material llamado también elementalista, cósmico, por cuanto presume que es en el objeto material donde se condensa el máximo de energía psíquica y de voluntad humana. La ambigüedad ya se hace evidente sobre todo cuando en la Poética del espacio propone el topoanálisis como auxiliar del psicoanálisis, entendido aquél como "el estudio psicológico sistemático de los parajes de nuestra vida íntima”.

4 En La formación del espíritu científico distingue diferentes edades del pensamiento científico: precientífica, científica, y nuevo espíritu científico (a partir de 1905 
filosofía que le sea adecuada, filosofía abierta como la denomina, capaz de dialectizar la experiencia, los conceptos y las teorías. Filosofía que a su vez se dispersa ya que nunca pierde de vista que: "Cada hipótesis, cada problema y experiencia, cada ecuación reclamarían su filosofía" (La filosofía del no 15).

Desde la tesis doctoral de 1928, un postulado de su epistemología es la afirmación del conocimiento como movimiento, como esfuerzo continuo de creación, se lee desde las primeras páginas de Essai sur la connaissance approchée. Ahora bien, esta concepción del conocimiento como inacabado, coma evolución del espíritu, susceptible de ser asimilada a la idea bergsoniana de élan vital, es solidaria con los caracteres por los cuales se puede especificar la actividad científica: inducción, creación, dialéctica. De ahí el sentido de las expresiones “inducción que descubre”, “construcción”, “invención”, particularmente útiles para comprender que la ciencia es producción de objetos, es trabajo de creación y no de reproducción de lo real inmediato.

con la teoría de la relatividad) con sus correspondientes estados del alma (pueril, alma profesoral, y alma en trance de abstraer o quintaesenciar). La edad precientífica comprende desde la Antigüedad Clásica hasta el siglo xviII. Como se ve, sin amplios períodos del pensamiento científico los que quedan asignados por la categoría precientíficos. Lo precientífico viene a ser esa forma de pensamiento unitario que apoyada en un realismo ingenuo y en una doctrina de lo general está girando alrededor de intereses pueriles propios de la curiosidad coleccionadora o del afán de satisfacer la curiosidad. "Para el espíritu precientífico la unidad es un principio siempre deseado, siempre realizado como poco esfuerzo. Nos hace falta más que una mayúscula. Las distintas actividades naturales se convierten así en manifestaciones de una única y misma naturaleza. No se puede concebir que la experiencia se contradiga y tampoco que se separe en compartimentos de una única y misma naturaleza. No se puede concebir que la experiencia se contradiga y tampoco que se separe en compartimentos. Lo que es la verdad para lo grande debe ser verdadero para lo pequeño e inversamente. Frente a la menor dualidad se sospecha un error. Esta exigencia de unidad plantea una cantidad de falsos problemas" (La Formación del espíritu científico 103). A la luz de estas características que acabamos de enunciar, la pregunta que nos planteamos es la de saber si nuestro autor no cae también en una generalización arriesgada en el tiempo. Se sabe, en efecto, que con Galileo comienza la ciencia moderna, concretamente la física, que el mundo que él describe contradice la experiencia común y que el experimento científico construido sobre una teoría matemática no tiene nada en común con la experiencia cotidiana. 
Bajo la expresión global de búsqueda de hechos nuevos, desconocidos, encontramos una pluralidad de elementos diferentemente asociados, por ejemplo, la creación de nuevas formas, que enfatizan todas las perspectivas revolucionarias de la actividad científica. "Conocer es describir para descubrir" (Essai sur la connaissance 9). Esta afirmación se presenta como una constatación de lo que significa hacer ciencia hoy cuando la microfísica ha operado ya un desplazamiento del objeto más allá de la experiencia de los sentidos. Es, por lo tanto, la noción de objeto la que merece una atención especial con respecto a la ciencia noumenal (la microfísica), ya que se modifica el marco de la organización misma del conocimiento.

Una de las condiciones para la objetividad de la ciencia de hoy es precisamente la de que el espíritu no puede tomar una imagen por un objeto. Su definición del átomo es bien ilustrativa: el átomo es "la suma de críticas a las que se somete su primitiva imagen”. Como cada saber se construye produciendo, creando objetos que se presentan como realidad y llegan a ser cada vez más específicos y diferenciados gracias a la dinámica propia de la racionalidad, hay un "compromiso objetivo" en toda ciencia y que se sintetiza en una escala de precisión, una sucesión de aproximaciones y una exigencia de especialización.

Por eso en la búsqueda de las nuevas raíces de la objetividad llega a establecer que el "objeto es la perspectiva de las ideas" (Essai sur la connaissance 246), noción indispensable para comprender la crítica al cosismo y al ideal pedagógico de ver para comprender ${ }^{5}$.

La ciencia ya no puede ser entonces una lección de cosas ni tampoco la enseñanza de la experiencia cotidiana. En su proceso de construcción-reconstrucción del objeto, el conocimiento científico es el resultado del encuentro con nuevas experiencias, nuevos métodos y

5 La enseñanza de las ciencias no puede reducirse a comparaciones y fáciles asociaciones con el objeto de hacer más inteligible el fenómeno que se busca explicar. En El materialismo racional, el blanco de las críticas es precisamente María Montessori y sus lecciones de química a través de imágenes que ilustran, pero no explican; por ejemplo, que "el carbono tiene 4 brazos", imágenes que más bien contribuyen a una forma de retardo del adolescente. Es preciso contraponer a esas satisfacciones baratas la penumbra de las dificultades propias del conocimiento científico, "claridad es a veces una seducción que cobra víctimas en las filas profesorales” (186). 
sucesivas rectificaciones que se alejan cada vez más del dato inmediato. En esta dirección cobra importancia la distinción entre objeto percibido (fenomenal) y objeto pensado o científico (noumenal), instancias entre las cuales no hay un punto común pero que, en el fondo, sin duda, permiten establecer una especie de superioridad del racionalismo sobre el empirismo reflejada específicamente en una crítica constante al conocimiento común y en la afirmación del progreso como el progreso de la razón.

El racionalismo científico manifiesta su fecundidad si es aplicado y conquista la objetividad a través de sus aplicaciones. Pero para la objetividad del conocimiento no basta solamente que hablemos "del objeto para que nos creamos objetivos”, es necesario ante todo romper con el objeto inmediato, contradecir pensamientos anteriores surgidos de la primera observación y mantener una vigilancia "malévola" que impida a la inmediatez disfrazarse de objetividad. La crítica se plantea entonces como una exigencia total: crítica de la sensación, del sentido común e inclusive de las etimologías porque estas pueden ser engañosas. Por este camino encontramos lo característico del racionalismo aplicado: es la articulación de unas verdades de razón y unas verdades de experiencia. Pero por experiencia se entiende aquella que viene mediada por el conjunto de aparatos, de instrumentos, que ya no son los simples auxiliares de la actividad científica sino teorías materializadas ${ }^{6}$.

\section{La epistemología es histórica}

En cuanto tal, se propone explicar la naturaleza de una ciencia y su proceso de formación en el tiempo, y para ello toma en cuenta una noción que le es inherente, la de progreso; de tal manera que la ciencia misma es definida aquí como un "progreso del saber espiritual".

6 En esta misma dirección, Koyré muestra cómo ya los instrumentos galileanos (telescopio, péndulo) son realizaciones de teorías. Con el análisis de la "fenomenotecnia" comprendido desde 1931 Bachelard quiere hacer más evidente su idea de que es el racionalismo el que instaura los fenómenos y que la ciencia contemporánea más que una descripción es una producción de fenómenos. La fabricación de fenómenos ("el fenómeno es un tejido de relaciones") y la técnica de efectos (el efecto Raman, el efecto Compton) desvirtúan, según él, la creencia en que las cosas pueden instruirnos directamente. 
Ante las racionalidades progresivas como son las ciencias, las tareas del epistemólogo y las del historiador no se separan, ya que la historia de las ciencias es concebida como "la historia de las derrotas del irracionalismo" y en este sentido no puede reducirse simplemente a la veneración del pasado y al registro de los hechos y las teorías. Es más bien una historia que va del presente al pasado, que juzga el pasado con base en certezas del presente; es la historia recurrente, y en cuanto tal "descubre en el pasado las formaciones progresivas de la verdad".

La historia de las ciencias así concebida presenta una doble orientación: una historia caduca de corta duración de los conceptos (la teoría del flogisto) y una historia sancionada en la que los conceptos son para siempre conceptos científicos. Al juzgar ese pasado espiritual se hacen evidentes los valores de la ciencia (el valor de racionalidad, el valor pedagógico) y se impone el abandono de las valoraciones subjetivas, de los realismos ingenuos. Frente a ese pasado la historia de las ciencias se convierte en "un tejido de juicios implícitos sobre el valor de los pensamientos y de los descubrimientos científicos" (El compromiso racionalista 152 ).

Cuando se considera que las ciencias en su desarrollo histórico poseen una dinámica propia, la del progreso, se comprende el interés del autor por examinar ese campo heterogéneo y movedizo de las imágenes, prejuicios, valoraciones subjetivas que, de una y otra manera, pueden convertirse en trabas para la constitución del conocimiento científico. Son los obstáculos epistemológicos. Desde una problemática bien próxima a la del autor de la teoría de los ídolos cuando se propuso investigar por las causas del error y purificar la mente de toda clase de prejuicios, Bachelard advierte igualmente la necesidad de una catarsis "intelectual o afectiva" para la purgación de nuestras imágenes, representaciones simbólicas y convicciones individuales.

La noción de obstáculo, obtenida de la función que desempeñan los contrapensamientos en el desarrollo del conocimiento científico no remite a una colección de errores sino más bien, como lo indica Michel Serres, a unos vicios del pensamiento o pecados capitales de la no-ciencia (orgullo, avaricia, lujuria, gula) que tienen por soporte común la ausencia de crítica, el empirismo inmediato, la subjetividad de las valoraciones y la satisfacción fácil e inmediata de la curiosidad. Su variedad, 
examinada con abundantes detalles y ejemplos en La formación del espiritu científico, se puede apreciar en la simple enumeración:

1. La experiencia básica

2. El conocimiento objetivo

3. El obstáculo verbal

4. El conocimiento unitario y pragmático

5. El obstáculo sustancialista

6. El realismo

7. El obstáculo animista

8. El mito de la digestión

9. El obstáculo constituido por la libido

10. Los obstáculos del conocimiento cuantitativo

Sin remontarnos a cada uno de ellos, es preciso agregar una exigencia elemental previa a todo ese análisis detallado y ejemplificado. Si la ciencia se explica por una voluntad de razón, por una voluntad de saber, el primer obstáculo que debe superar es la opinión, pues ella lo único que pone de manifiesto es la incapacidad para plantearse problemas, indicio seguro de que no puede aportarnos más de lo que nos ofrece el sentido común. Por el contrario, el sentido del problema, tan profundamente inscrito en el movimiento mismo de la conciencia creativa, es precisamente lo que la opinión no puede proporcionarnos.

Detengámonos en el obstáculo que surge directamente del lenguaje, tratado severamente en la medida que le permite establecer la tesis de que el lenguaje científico se caracteriza por una "permanente revolución semántica” que pone en evidencia el desfase entre la subsistencia de las palabras y las variaciones de los conceptos, así como la confrontación o ruptura entre lenguaje común y lenguaje científico. Los ejemplos son bien ilustrativos (la esponja, la botella de Leyde) para explicar las diferencias entre las significaciones del lenguaje usual y las del lenguaje científico y la evidente discontinuidad entre ambos.

El abuso con las palabras y las posibles trampas a las que nos puede conducir el lenguaje tan característico del conocimiento vulgar son premisas para la afirmación del lenguaje científico como un neolenguaje y del concepto científico como "una verdadera emergencia del 
conocimiento", tal como se puede apreciar en la formación del concepto de capacidad eléctrica (El materialismo racional 24). Es también ese aspecto el que puntualiza Canguilhem cuando afirma que "ciertamente las palabras no son los conceptos que ellas movilizan". La palabra esponja es el prototipo del obstáculo verbal y de la imagen generalizada. Sirvió para definir el hierro (es una esponja del fluido magnético), para la definición de los vidrios (son esponjas de luz); Réaumur explica el aire como una esponja y Descartes acude a la "esponja hinchada de agua o de otro líquido" para explicar la rarefacción. En síntesis, el uso abusivo del lenguaje puede conducir fácilmente a la imprecisión, a falsas representaciones y a las más variadas explicaciones.

El riesgo que se corre por el peso del lenguaje sobre el pensamiento nos hace pensar en la prolongación de una línea de pensamiento ya marcada por Descartes, Bacon y Spinoza cuando examinan las causas del error ${ }^{7}$.

Le corresponde a la ciencia y al hombre de ciencia en particular convertir su actividad en una búsqueda constante de precisión, de afinamiento y de clarividencia, pero esta tarea no es simple, existe siempre una serie de intuiciones primeras, imágenes, prejuicios, que pueden frenar el proceso de objetivación. La noción de corpúsculo de la física contemporánea tuvo que cargar el peso de la noción-obstáculo de corpúsculo concebido como un cuerpo pequeñito. La creencia

7 Para Descartes, una de las causas de nuestros errores está en que pensamos más con las palabras que sobre las cosas: "y los pensamientos de casi todos los hombres versan más sobre las palabras que sobre las cosas. A tal punto que muy a menudo prestan asentimiento a vocablos no comprendidos, porque piensan que los han comprendido antes, o los han recibido de otros que los han comprendido bien" (Los principios de la filosofía 34). Si bien para Bacon el lenguaje es concebido como el instrumento de la comunicación humana, sin embargo, advierte sobre el peligro de la formación de ídolos del foro o falsas nociones se que originan cuando el significado de las palabras "se regula por el concepto del vulgo". Expresión esta que paralelamente aparece en Spinoza para designar a todos aquellos que no poseen el conocimiento verdadero de las cosas y expliquen su naturaleza a través de una de las formas de la imaginación, a saber, el lenguaje. Las palabras "están formadas arbitrariamente y como le complace al vulgo, hasta tal punto que no son sino signos de las cosas según se dan en la imaginación, pero no como se dan en el entendimiento" (Tratado de la reforma del entendimiento 52). 
en la riqueza del dato o realismo ${ }^{8}$, realismo del olfato y realismo del sabor, fue un obstáculo para la experiencia química y, en cuanto tal, procede de un sentimiento del poseer que se identifica con la avaricia o complejo de Harpagon.

Como los obstáculos no son externos, sino que están en el sujeto en el acto mismo de conocer, un psicoanálisis del conocimiento objetivo será muy propio para ir a la búsqueda de las condiciones o espacio en el que se despliegan las imágenes, las prenociones y los prejuicios. Será preciso entonces desterrar todo este repertorio para que un conocimiento sea llamado objetivo. En estas condiciones, la noción de objeto no designa, en el contexto de la actividad científica, más que "un complejo de relaciones" bien alejado de un simple contacto con el mundo real del que se pudiera seguir la acción de la percepción. El punto de partida para la ciencia contemporánea no es la realidad, stricto sensu, sino un modelo teórico coherente.

Desembarazar el sujeto de los obstáculos que se le presentan en el acto mismo de conocer no es otra cosa que contribuir a "arrancarlo del narcisismo que da la evidencia primera". Aquí el psicoanálisis es catártico, permite curar, mientras que en la producción artística ayudará a comprender el desarrollo de la imaginación. Sin embargo, ese interés por el inconsciente en la actividad científica constantemente oscila entre una psicología del cogito científico y la búsqueda de arquetipos en el inconsciente o entre la búsqueda de condiciones psicológicas del progreso científico y la constitución de un psicoanálisis, curiosamente llamado, psicoanálisis psicológico. Por otra parte, la objeción de psicologismo a la que Bachelard trata de responder en varias ocasiones es planteada por Quillet cuando se pregunta si la ciencia no encuentra otros obstáculos diferentes de los psicológicos.

Las limitaciones de una epistemología demasiado antropológica no las pierde de vista Annie Guédez cuando evoca el parentesco de

8 En La valeur inductive de la relativité (1929) el realismo es definido así: "toda doctrina que mantiene la organización de las impresiones al nivel de las propias impresiones, que por consiguiente cree en la riqueza prolija de la sensación individual y en el empobrecimiento sistemático del pensamiento que abstrae" (206, la traducción es nuestra). 
Foucault con Bachelard. Pero cuando se toma en consideración solamente el papel negativo del obstáculo en la historia de la ciencia, ¿esto es garantía suficiente para una auténtica historia de dicha ciencia? Porque hay unos obstáculos bien definidos con los cuales choca el espíritu científico y que no responden necesariamente a una fijación psicológica.

Así, por ejemplo, desde una perspectiva diferente François Russo insiste en unos tipos generales de racionalidad (el rigor o simple respeto de las normas de la lógica, la acogida a la novedad, la razón crítica) pero que no dan cuenta totalmente del progreso en el conocimiento científico. Es necesario, según él, examinar la manera como se conjugan la racionalidad y la no racionalidad para asegurar dicho progreso. El rechazo a abandonar el círculo, por ejemplo, fue un obstáculo para el advenimiento de la astronomía moderna: como símbolo del tiempo sirvió para indicar la totalidad, la perfección, la armonía, y es esta concepción comúnmente admitida la que subyace en la pregunta de Plotino sobre el movimiento circular del cielo.

Además del rechazo a la novedad por motivos más de tradición o estéticos que lógicos, es preciso recurrir a otros factores que en mayor o menor grado pueden ser favorables o desfavorables al progreso de la ciencia, no solo psicológicos sino también externos, sociológicos ${ }^{9}$, económicos.

La existencia de obstáculos epistemológicos en el pensamiento científico y su develación hace parte junto con la noción de ruptura y el concepto de ciencia de los aportes fundamentales de Bachelard a la epistemología contemporánea. Canguilhem lo ha visto así claramente

9 Así, F. Russo encuentra la coexistencia en científicos del siglo XVII, de un gran rigor lógico y fallas de racionamiento, como en el jesuita Gregoire de Saint Vincent en relación con la formación del cálculo infinitesimal, o el error de razonamiento del jesuita J. G. Saccheri (1667-1733) sobre el postulado de las paralelas y la constitución de la geometría no euclidiana. Entre los factores psicológicos F. Russo incluye los siguientes: el prestigio de un gran científico, la presión ejercida por el medio intelectual y la comunidad científica. Recordemos que desde una perspectiva netamente "externista", J. Needhan se pregunta: ¿̨or qué la ciencia moderna nació en Europa en los siglos XVI y XVII y no en la China? y responde con un estudio sociológico e histórico. 
cuando en sus reflexiones sobre la biología muestra que Harvey, para comprender y explicar la circulación de la sangre, se encontró precisamente con el obstáculo de la imagen de la irrigación del suelo ( $E l$ conocimiento de la vida).

\section{La ruptura}

Es una categoría presente en toda la obra y está ligada estrechamente a su concepción del conocimiento científico. Por otra parte, es sorprendente el puesto que actualmente ocupa en las ciencias humanas y quizá como lo señala Lecourt haya contribuido a malentendidos y usos exagerados. En la lectura de Marx, Althusser propone una ruptura epistemológica ${ }^{10}$ que separa los trabajos del joven Marx de los textos científicos de madurez. Ruptura que marca la mutación de una problemática precientífica, distinción entre ideología y ciencia como forma elaborada y aproximada de la oposición radical de Bachelard entre espíritu precientífico y espíritu científico, conocimiento común y conocimiento científico. Por otra parte, Foucault en Las palabras y las cosas señala la ruptura de los campos de pensamiento.

La Enciclopedia Universalis define el "corte epistemológico" como "el momento en que una ciencia se constituye cortando con su prehistoria y sus entornos ideológicos" y cita como ejemplos la constitución del materialismo histórico, el psicoanálisis, la física moderna con Galileo. Una concepción que afirma la ruptura entre la ciencia y la no ciencia es evocada explícitamente por Philippe Rivière y Laurent Danchin cuando explica la aparición de la lingüística como ciencia, a partir de Saussure, por el entrecruzamiento del método y del objeto, por una parte, pero sobre todo por el abandono y el desplazamiento (Linguistique et culture nouvelle 18).

Conviene entonces abordar dicho concepto en Bachelard mismo ya que, como lo hemos visto, su análisis del pensamiento científico nos obliga a abandonar esa bella imagen de la ciencia como un edificio

10 En 1876 Dedekind utilizó coupure para exponer su teoría de la continuidad aritmética. Sin embargo, Althusser lanzó la expresión coupure épistémologique (literalmente, "corte epistemológico", pretendiendo tomar en préstamo el concepto de rupture de Bachelard. 
que se construye paulatina y pacientemente en un esfuerzo sin fin y progresando siempre por acumulación, como si estuviera siguiendo estrictamente un modelo lineal. Por el contrario, afirma en la conclusión del Materialismo racional, no sin antes haber puesto en tela de juicio la cadena necesaria y causal del antes sobre el después, que "creemos, en efecto, que el progreso científico manifiesta siempre una ruptura, perpetuas rupturas" (128).

Entre la alquimia y la química no existe una relación de causalidad sino de obstáculo. La ciencia no progresa por sumatoria ni acumulación, sino mediante rupturas y revoluciones de ideas que la renuevan, negando verdades anteriores o verdades de siempre, inclusive desprendiéndose cada vez más de su pasado y recomenzando hasta en sus propios cimientos. Por eso la filosofía que más le conviene al conocimiento científico es el racionalismo entendido como en el que las matemáticas o el esperanto de la razón ocupan un lugar considerable. De ahí las expresiones ciencia racional y técnica racional para significar que están inspiradas en las matemáticas y que sus símbolos están más allá de las imágenes del conocimiento común.

Como se puede apreciar enseguida, el filósofo francés utiliza desde muy temprano (desde la tesis doctoral) el concepto ruptura (coupure), inicialmente en el sentido de la ruptura de un saber con saber anterior: "en la evolución histórica de un problema particular no se pueden esconder verdaderas rupturas, mutaciones bruscas que arruinan la tesis de la continuidad epistemológica" (Essai sur la connaissance approchée 270).

El contexto de esta afirmación lo constituye el problema de las concepciones de Goethe sobre la luz y las teorías de Fresnel con la consiguiente aclaración de que las teorías de este último no responden a las preguntas dejadas en suspenso por los científicos que le precedieron. Y, paralelamente, al comienzo de la obra consagrada a la física del calor, denuncia la creencia en que:

los problemas científicos se suceden históricamente por orden de complejidad creciente sin que se haga ningún esfuerzo por reubicarse críticamente ante el problema tal como se ofrece a la observación primitiva y sin definir en qué aspecto se tiene 
un problema por complejo (Etude sur l'évolution d'un problème de physique 20)

Por lo demás, este aspecto de la ruptura apunta directamente a la física y a la química en su desarrollo contemporáneo. Por eso, sin reservas, constantemente evoca la ciencia de nuestro tiempo en ruptura con la ciencia clásica; la ciencia de nuestro tiempo está articulada por ese vector que va de lo racional a lo real y donde precisamente ya lo real no se concibe como lo inmediatamente dado, sino en relación con la razón y representa para el conocimiento científico "un simple pretexto". La ciencia contemporánea es, a su manera de ver, la gran entrada en el reino de la razón.

Bajo otros matices, Bachelard quiere eliminar la idea de que todo conocimiento científico se puede reducir, en últimas, a los datos de los sentidos. La desensualización del conocimiento toma como ejemplos privilegiados el descubrimiento del ozono y el fenómeno del rocío (cuando se creía que este caía del cielo o brotaba de las plantas) para afirmar la tesis de la ruptura entre conocimiento común y conocimiento científico con sus correspondientes instancias filosóficas (empirismo y racionalismo). La ciencia se construye en ruptura con la evidencia sensorial, con los juicios de valor (bueno/malo) y con los principios de utilidad y finalidad. En el conocimiento común el objeto es apenas fenómeno, sin mayor significación y capacidad de recibir nuevas modificaciones, mientras que en el conocimiento científico es noúmeno, puede modificarse con nuevas experiencias y pensarse con otros pensamientos que constituyen, en últimas, el signo de la progresividad.

Finalmente, otro aspecto que sirve de marco a la elaboración del concepto de ruptura es el conocimiento técnico como dominio de racionalidad y progreso que se separa netamente del conocimiento común. Ruptura entre experiencia común y experiencia científica, experiencia cotidiana y experimento científico, nos conducen ahora a localizar el papel de los instrumentos en la fabricación de fenómenos.

De hecho, los instrumentos o aparatos de la experimentación son “encarnaciones de la teoría” (lo hemos visto también en Koyré) tan profundamente fecundos para la actividad científica que son inseparables del pensamiento. 
El examen particular de una fenomenotecnia, el descubrimiento de la bombilla o técnica de no combustión de Edison, muestra una ruptura con todas las técnicas de alumbrado anteriores no solo por sus características de globo de vidrio, encerrado en el que está colocado un filamento, lo que ya presupone un gran conocimiento de la combustión, sino también por el abandono de una concepción sustancialista de la electricidad del siglo xvin que establecía como equivalentes el fuego, la electricidad y la luz. A esta ruptura con el empirismo de la combustión se la denomina técnica racional, esto es, expresada en fórmulas matemáticas (es la ley de Joule la que la regula y su expresión algebraica pone en relación los conceptos de energía, resistencia intensidad y tiempo: W = RI2t (W: energía, R: resistencia, $\mathrm{I}$ : intensidad, t: tiempo).

La diferencia entre el nivel de lo inmediato (lo percibido) y el nivel de los construido (las ciencias y sus teorías), así como la reiterada insistencia en que el conocimiento científico no es una traducción de lo sensible, fundamenta una vez más la tesis de la ruptura: "Existe ruptura entre el conocimiento sensible y el conocimiento científico. Se ve la temperatura en un termómetro, pero no se la siente. Sin teoría no sabríamos jamás si lo que se ve y se siente corresponden al mismo fenómeno". (Filosofía del no 12)

Para que un conocimiento sea llamado científico el criterio es el de que esté comprometido, esto es, que haya pasado por la criba de las rectificaciones mediante las cuales es dirigido e impulsado incesantemente a nuevas conquistas. El invento de la máquina de coser no fue posible, sino mediante una ruptura con la costumbre cotidiana de producir a mano la costura.

\section{El alma profesoral}

Con La formación del espíritu científico Bachelard quiso purgar el pensamiento científico de toda forma de subjetividad y de anquilosamiento en el conocimiento cotidiano. En esas condiciones se sigue claramente el propósito de una pedagogía de la razón que se rija por el principio de hacer evidentes los valores científicos, el de racionalidad y el pedagógico, únicos capaces de hacernos comprender la importancia de la 
ciencia. De ahí proviene la intención pedagógica presente en sus obras y expresada constantemente en un esfuerzo por contribuir a la renovación de la práctica pedagógica. A los niños no se les debe enseñar únicamente observando en el laboratorio cómo se hace un experimento, sino ante todo llevándolos a comprender y a construir el conocimiento, es decir, estimulando una voluntad de saber o complejo de Prometeo. Por eso, apoyándose en los trabajos del conde Korzybski advierte que "el niño nace con un cerebro inconcluso y no con un cerebro desocupado, como afirma la pedagogía antigua” (Filosofía del no 106).

"No hay ciencia sino mediante una escuela permanente". Este es un postulado que resume la necesidad de una formación permanente en el educador, ya que "es imposible educar por simple referencia a un pasado de educación. El maestro debe aprender enseñando y fuera de su enseñanza" (107).

Si no es así, institucionaliza una práctica muy antigua, bien cerrada, de enseñar desarrollando lo conocido o repitiendo cada año su saber a la manera de un pedagogo aristotélico firmemente aferrado al principio de identidad. Será necesaria entonces una "cultura continuada" en correspondencia con los progresos científicos más allá del tiempo escolar y de los programas preestablecidos.

“Todo lo que es fácil de enseñar es inexacto". Es un aforismo que pone de manifiesto la actitud deplorable del pedagogo positivista empeñado en adoptar métodos que aseguren una mejor comprensión pero que al mismo tiempo están paralizando el pensamiento, pues si no se inquieta la razón se bloquea esa capacidad de construir que caracteriza a un organismo abierto. ¿De qué manera podría ser educativa —se pregunta Bachelard — la imagen del átomo planetario o la del átomo-sol de Raspail? Esta sería precisamente una forma de pedagogía de la continuidad entre conocimiento común y conocimiento científico con la que hay que romper.

“Todo conocimiento científico es una penumbra de dificultades" y, por lo tanto, lo único que disfruta de una existencia plácida y tranquila es el empirismo cotidiano. En síntesis, tanto el comprender como el hacer comprender plantean una misma exigencia; esto quiere decir que para la práctica pedagógica será más interesante examinar cómo se suceden las teorías, cómo se enfrentan y cómo se superan. La enseñanza 
de las ciencias se orientará entonces a demostrar que estas poseen una dinámica propia y un devenir tal que las ponen en conexión cada vez más estrecha con una actividad que se crea y con una invención que constantemente se está haciendo y deshaciendo a lo largo de su historia. La ciencia debe enseñarse con los lentes de una dialéctica histórica, advierte enfáticamente.

Resulta bien significativo que con la expresión logoses catatoniques (conferencia en L'Ecole des Hautes Etudes de Gand en 1939) denuncie el drama pedagógico de las falsas racionalizaciones, las falsas analogías, la aceptación del empirismo absoluto, y proponga una educación intelectual "catártica" que contribuya a "desanclar" la razón. Las falsas racionalizaciones (logoses) tienen como soporte el modelo inspirado por la pedagogía misma en cuya base está la idea de adaptación a una determinada forma de sociedad, a una razón ya constituida y a un principio de autoridad.

\section{La poética}

$\mathrm{Al}$ abordar esa otra vertiente de la obra bachelardiana, la filosofía de la imaginación, es preciso resaltar ante todo la reciprocidad que aparece entre existencia y derecho de soñar, pues no es solamente la imaginación lo que constituye el objeto de la reflexión sobre la creación artística, sino también la propia ensoñación de Bachelard, la mezcla en que se juntan los recuerdos de infancia marcados por el agua y el estudio de las imágenes del agua. A través del contacto con la poesía y las imágenes literarias de poetas y escritores (Rimbaud, Mallarmé, Éluard, Shelley, Edgar A. Poe) Bachelard pasa a la apreciación de las imágenes en las artes plásticas en una actitud que bien define Maurice-Jean Lefebvre cuando afirma:

comprender, cuando se trata de arte, literatura, así como de música es coincidir. No es tener la obra a distancia bajo una mirada objetiva dentro del campo del microscopio del análisis o del telescopio de la historia literaria; es intentar reproducirla en nosotros y vivirla. (L'image, la psychanalyse et l'explication littéraire 23) 
En el marco de una estética de lo humano, la reciente publicación póstuma de los Fragmentos de una poética del fuego se inscribe en la gran trilogía iniciada con La poética del espacio y La poética de la ensoñación. El retorno al tema inaugural de la imagen ígnea ya explorada en El psicoanálisis del fuego a través de los complejos de Prometeo y Empédocles le otorga ahora a estos héroes una nueva dimensión. Prometeo es más que un humano. Y Empédocles es una de las más grandes imágenes de la poética de la aniquilación. Poética de la aniquilación y al mismo tiempo del heroísmo en la que es preciso destacar ante todo sobre el plano de la dualidad animus-anima una constante acción del animus o arquetipo de lo masculino y de los proyectos violentos ${ }^{11}$.

Pero en el examen de este cosmodrama de la muerte de Empédocles es el poema de Hölderlin el que ocupa un lugar considerable junto a Arnold y Nietzsche, anota Bachelard.

Al hablar de poética en Bachelard, filósofo de la ciencia y de la poesía, de la imagen y del concepto, de la ensoñación y de la razón, un aspecto que ha de tenerse en cuenta inicialmente es el significado mismo de poética, concepto que no propuso desarrollar directamente pero que, sin embargo, se podría aproximar a lo que Valéry entiende por poética.

De esta definición se descarta, por consiguiente, todo lo que consiente a los presupuestos normativos en la poesía otorgando, más bien, todo el peso a la fusión entre creación y lenguaje, universo poético y lenguaje, tal como lo resume la afirmación, la poesía es un arte del lenguaje $^{12}$. De hecho, no es difícil conciliar precisamente esta definición con otra de las definiciones bachelardianas de poesía: "la poesía es uno de los destinos de la palabra. Por ello, la poesía, la imagen literaria, nos brindan la experiencia de una creación del lenguaje" (El aire y los sueños 306).

11 Fragments d’une poétique du feu es una obra póstuma cuya publicación autorizó su hija Suzanne Bachelard. Sin embargo, Jean Lescure, íntimo de Bachelard, había publicado en 1983 Un été avec Bachelard donde recoge fragmentos de lo que iba a constituir una introducción a La poétique du Phénix.

12 Paralelamente en los Fragments d'une poétique du feu encontramos la afirmación "La poesía, la poética es un verdadero reino del lenguaje" (54). 
Es, sin duda, la razón para que el soñador de palabras, como solía definirse, encuentre en la imaginación los principios mismos de la creación artística y señala que es bajo el signo de la conciencia de lenguaje como es posible aproximarse a ella. Es mediante la palabra que la imagen literaria cumple en todas las modalidades la doble función irremplazable desde la perspectiva de las imágenes como realidades psíquicas que constantemente están reclamando vida nueva. Por consiguiente, la originalidad y la novedad constante son rasgos específicos de la imagen literaria, porque si ella es un sentido en estado naciente, como lo pretende Bachelard, se dirá entonces que el lenguaje es instrumento de creación y que es a través de la literatura como podemos apreciar tanto la explosión y la creación de lenguaje como la aparición de un universo propio. Es lo que significan, en último término, la literatura como "una emergencia de la imaginación" y correlativamente la imagen poética como una emergencia del lenguaje. Tal es el sentido de esa vida nueva presente en la imagen poética que el poema mismo se designa como una aspiración a imágenes nuevas y la poesía como un comienzo permanente.

No es extraño que con estas afirmaciones asocie también una teoría del conocimiento científico como creación continua y movimiento inacabado e inicie su reflexión sobre la ciencia asignándole a esta la tarea de buscar hechos nuevos, hechos desconocidos. Si la actividad científica no es otra cosa que creación, inducción y dialéctica, entonces la creatividad se convierte en un valor inherente a la ciencia. Por esto, el situar sistemáticamente la inducción que descubre y la imagen poética como expresión de un ser nuevo en un mismo movimiento de invención, Bachelard va a permanecer fiel a esa idea de que "la ciencia es la estética de la inteligencia” y que, en consecuencia, en tanto creación, guarda cierta semejanza con la creación artística. La novedad es el signo del acto científico y de la capacidad creadora del lenguaje que nunca termina de nacer y de renacer es justamente "símbolo de una eternidad que vive".

En una de las poéticas, la del espacio, antes de emprender el examen de las imágenes del espacio feliz (la casa, el cajón, del nido, las conchas, el rincón evocador de ensoñaciones y recuerdos de soledad) nos advierte que la imaginación debe ser considerada como "una potencia 
mayor de la naturaleza humana" (Poética del espacio 28), una especie de sobrehumanidad a la que le corresponde la función de lo irreal. Lo que legitima el invento de la navegación en canoa no es la utilidad y la necesidad sino la curiosidad, y análogamente, en el sueño de vuelo como realidad nocturna está subyacente al principio del deseo de volar (El aire y los sueños 40). Por paradójico que aparezca, es la poética la que une las dos funciones extremas, la función de lo real y lo irreal, psíquicamente útiles inclusive para protegerse contra la neurosis.

$\mathrm{Al}$ afirmar la realidad de lo irreal o que lo irreal puede ser también real, es imprescindible volver sobre la célebre fórmula en la cual André Breton encierra en cierta manera a lo imaginario: "Lo imaginario es lo que tiende a llegar a ser real". Todo lleva a creer, afirma en el Segundo manifiesto del surrealismo, que existe un cierto lugar del espíritu desde donde la vida y la muerte, lo real y lo imaginario, lo alto y lo bajo, dejan de ser percibidos contradictoriamente.

Sin pretender abarcar el desarrollo del surrealismo (pintura, literatura, música, escultura), sus antecedentes y vertientes (el abstraccionismo), sus características iniciales de rebeldía y libertad, no hay duda de la importancia capital que este movimiento tuvo en el desarrollo del pensamiento de Bachelard no solamente en el tratamiento de los temas ligados a la imaginación, sino también en la puntualización del nuevo racionalismo (reorganización supranacional de lo real) por simetría con el surrealismo que "como el sueño experimental de Tristán Tzara organiza de un modo superreal la libertad poética", afirma en 1934). No sorprende que más tarde, al ocuparse de las ensoñaciones del aire, plantee la posibilidad de una "filosofía que explique lo real por lo imaginario" (105) y que al estudiar las ensoñaciones de la tierra alce su voz contra los realistas que:

Atribuyen todo a la experiencia de los días olvidando la experiencia de las noches. Para ellos la vida nocturna es siempre un residuo, una secuela de la vida despierta. Proponemos poner de nuevo las imágenes en la doble perspectiva de los sueños y los pensamientos. (La tierra y las ensoñaciones del reposo 130)

No deja de ser importante que en 1939, más o menos por la misma época en que proponía un psicoanálisis del conocimiento objetivo 
con La formación del espiritu cientifico y El psicoanálisis del fuego Bachelard haya consagrado una obra a un poeta, Lautréamont, inspirador o más bien fecundador del movimiento surrealista, según expresión de Maurice Nadeau. Es una declaración que Bachelard comprendió muy bien al estudiar Los cantos de Maldoror del poeta de la agresión en la óptica de un psicoanálisis de la vida. Se trata de explorar en la obra de Isidore Ducasse el complejo de la vida animal y una fenomenología de la agresión, "agresión pura en el mismo estilo en que se habla de poesía pura”.

"El libro monstruoso", como lo viera Leon Bloy, es poética y psicológicamente "una obra acabada" y "una locura escrita", "una locura sin locuras" que rompe con las imágenes primeras, habituales o familiares del lenguaje cotidiano, ruptura con la estructura del mundo objetivo y que a su vez compromete la libre subjetividad del poeta. Por esto la poesía de Lautréamont crea su lenguaje, sus propios símbolos, es en este sentido progresiva, primitiva. Y, a diferencia de una imaginación que se adecúa al pasado o imaginación cerrada (por la vía de la percepción, el recuerdo), la imaginación abierta reposa sobre el cambio de formas, el proyecto, la metamorfosis. Y siendo esto así, recordemos que no deja de ligar Breton los nombres de Rimbaud y Apollinaire, Jarry y Lautréamont, precisamente cuando se refiere al desorden sistemático de las significaciones. Por eso cuando Éluard cita con admiración esa imagen de Lautréamont "encuentra en ella el eco y el espejo de sus propias preocupaciones".

Después de haber reconocido, a partir del frenesí de Lautréamont por la metamorfosis, que esta es una función de la imaginación, y, aún más, que la imaginación encuentra su origen en la necesidad de animalizar, Bachelard centra su atención en el concepto de imaginación material o imaginación de los elementos. Así, en El agua y los sueños (1942), obra que lleva por subtítulo Ensayo sobre la imaginación de la materia, cuando busca la raíz misma de la fuerza imaginante encuentra metafóricamente que "en la noche de la materia florecen flores negras” (9); lo que equivale a señalar una materia a las imágenes poéticas y establecer la "ley de los cuatro elementos," de los que se nutre la imaginación como si estos fueran sus hormonas. 
Los elementos son los principios de la creación artística, reitera a manera de conclusión después de haber examinado el elemento aéreo en la catedral de Rouen (Monet), el tema del agua en Las ninfas y el fuego en Van Gogh. Esta especie de determinismo tiende a mostrar que los cuatro elementos ejercen una acción en el espíritu poético, están presentes en él y operan mutaciones y combinaciones, son inductores de imágenes, operadores de imágenes. Al agua, sin duda, están ligados poéticamente Edgar A. Poe y las aguas pesadas dentro de la clasificación de las imágenes del agua (claras, primaverales, corrientes, enamoradas; aguas profundas, durmientes, muertas, pesadas, compuestas, dulces, violentas) y también Shakespeare cuando en Hamlet pone en relación la muerte con el agua, de donde surge precisamente el complejo de Ofelia.

Un complejo, afirma, es un transformador de energía psíquica, es la síntesis inacabada de sueños y deseos. Ofelia es el símbolo del suicidio femenino. Otros complejos que se desprenden de las imágenes que tienen por materia el agua son el de Caronte (el viaje sobre el agua y la muerte como viaje), el del cisne, el de Nausicaa (mezcla de deseos e imágenes de ninfas y nereidas), el complejo masoquista de Swinburne propio de los nadadores, el complejo sádico de Jerjes azotando las aguas, y el complejo de la fuente de Juvencio (síntesis del deseo de curarse y de soñar con la sustancia compasiva). Estos complejos, que se podrían multiplicar, constituyen, como lo sugiere Dagognet, una especie de atlas del espacio poético para seguir de cerca las trayectorias del psiquismo en acto. Los complejos llevan la marca de una huella profunda en el inconsciente. Un complejo como el de Anteo (horror al vacío, sensación de vértigo) lo encuentra Bachelard en Alejandro Dumas a partir de la lectura de Mis memorias.

El agua es por esencia femenina y como tal se destaca en su tipología imaginaria. El carácter femenino de este elemento será reconocido desde los detalles más simples como los nombres de los ríos (la Seine, la Loire, la Moselle) hasta la afirmación de nuestra pertenencia al agua por la asociación vida-muerte y la insistencia en la liquidez del lenguaje, el lenguaje debe estar henchido de agua. El agua es un elemento, una sustancia primordial para la imaginación, como también lo son el fuego, el aire y la tierra, cuatro tipos de imaginación material 
que el autor hace concordar con los cuatro temperamentos: el fuego caracteriza a los biliosos, la tierra a los melancólicos, el agua a los linfáticos y el aire a los sanguíneos. La materia gobierna a las formas, es un principio del que se vale para reconocerle a la imaginación este primer carácter específico al que luego se agregarán el formal y el dinámico; el dinamismo de la imaginación encuentra en el aire un tema explícito para instalarnos en su movilidad, como se verá más adelante en el estudio del psiquismo aéreo.

La ley de los cuatro elementos poéticos plantea la necesidad de precisar lo que se entiende por elemento que, a primera vista, aparecería Bachelard como directo heredero de Empédocles, si bien ya en el Psicoanálisis del fuego este elemento mantiene toda su importancia para caracterizar los complejos de Prometeo, Novalis, Hoffmann y obviamente el complejo de Empédocles (atracción y respeto por el fuego), complejo psicológico que una vez reconocido lleva al filósofo a preguntarse por qué el fuego, fenómeno en el fondo bien excepcional y extraño, que ha sido tomado por un elemento constituyente del Universo. $¿$ No es, acaso, porque es un elemento del pensamiento, el elemento de elección para la ensoñación? (La psychanalyse du feu 38). Esta pregunta, indiscutiblemente, introduce suficiente claridad, ya que el elemento es colocado sobre el plano funcional, esto es: la función imaginativa.

En este sentido, los elementos no son propiamente objetos, subraya François Pire. Son vectores de creación de nuestro espíritu más que percepción del mundo, precisa Ginestier. A la perspectiva propia de la imaginación de los elementos, es decir, cósmica, en cuanto son motores de nuestra visión del mundo, se liga necesariamente el psicoanálisis de los elementos, extraño propósito quizás pero que se convierte en un instrumento fundamental de la poética en los autores analizados. No faltarán expresiones para confirmarlo: inconsciente híbrido, el inconsciente del poeta, el inconsciente de Edgar A. Poe, etc.

De ahí el sentido de la tesis que adquiere la afirmación expresada en uno de los volúmenes consagrados a la tierra: "Toda materia imaginada, toda materia meditada, es inmediatamente la imagen de una intimidad" (La tierra y las ensoñaciones del reposo 14).

Aquí el elemento sigue manteniendo toda su importancia por cuanto no solo suministra abundantemente distintas imágenes poéticas 
del mundo del metal y la fantasía forjador (por ejemplo, las flores de hierro, la voluta), de la piedra y la roca, de los minerales y los cristales, sino también imágenes de intimidad y protección a través de la gruta, el vientre, la casa natal, el laberinto y la experiencia laberíntica.

Dentro de esta atmósfera elementalista, su teoría de la imaginación material va a desembocar en la dualidad propuesta por Jung entre animus/anima para explicar la constitución de la psique humana. De esta manera, según Bachelard, el inconsciente es a la vez andrógino y dialéctico ${ }^{13}$, en el sentido de que todas las representaciones, tanto femeninas como masculinas se complementan, se intercambian, se revuelven, cambien de posición, actúan recíprocamente. El anima es el arquetipo de las representaciones femeninas y el animus es el arquetipo de lo masculino; el sueño corresponde al animus y la ensoñación al anima.

En ambos casos, el inconsciente gira en torno al doblete constituido por aire y fuego como principios activos y masculinos, agua y fuego como pasivos y femeninos. Es esto precisamente lo que le permite decir en La poética de la ensoñación que "aquél que está marcado por el agua conserva fidelidad a su anima”, pero que también en la imaginación material el agua se combina con el fuego, "el agua extingue al fuego, la mujer extingue el ardor”. El agua, la luz, el árbol, la serpiente, la llama, son arquetipos, son fuentes de las imágenes poéticas y símbolos motores (el agua y el árbol son símbolos maternales), son "reservas de entusiasmo que nos ayudan a creer en el mundo, a amar el mundo, a crear nuestro mundo" (95).

La imaginación tiene sus raíces arquetípicas si bien, y esto resulta paradójico, frecuentemente está insistiendo en que no hay relación causal entre la imagen poética y el arquetipo cuando al mismo tiempo establece un nexo entre ambos. Así, a propósito de las imágenes (o imágenes primeras o grandes imágenes) no vacila en afirmar, apoyándose en Jung, que "las imágenes imaginadas son más bien sublimaciones

13 La utilización del concepto "dialéctica" exige una precisión, ya que constantemente nos vemos enfrentados a lo que Vadée denomina un uso "salvaje" del término: dialéctica de dentro y de fuera, juego dialéctica de la razón, dialéctica del enseñante y del enseñado, dialéctica de lo lleno y del vacío, dialéctica del espíritu científico, etc., son expresiones que dejan ver un uso deliberadamente libre para dar a entender la complementariedad, la acción recíproca, la sucesión alternante. 
de los arquetipos que reproducciones de la realidad" (La terre et les rêveries de la volonté 10$)$.

Las imágenes de la casa nos permiten evocar la protección, el amparo, la maternidad; los cajones, los cofres, el escritorio y sus cajones aseguran nuestra necesidad de intimidad; el rincón en el que nos acurrucamos resuelve nuestros deseos de inmovilidad; en las imágenes de la concha se concentra el deseo de reposo.

Se podrían multiplicar los textos en los que la terminología de Jung está presente, lo cual es bien significativo no tanto para hablar de influencias como sí de las posibles afinidades o coincidencias entre los dos. La poética de la ensoñación, ya se ha visto, está impregnada de la dualidad animus/anima y esta a su vez fue desarrollada ampliamente por Jung en El hombre y sus símbolos, dialéctica del yo y del Inconsciente, psicología y alquimia. Por otra parte, en una obra de epistemología como El materialismo racional, es evidente el propósito de hallar los arquetipos del inconsciente en la cuaternidad de los elementos en Agrippa y Platón y en el simbolismo alquímico.

Al considerar la afirmación bachelardiana de que la primera hipótesis científica sobre la invención del fuego es el amor y que la frotación es originalmente una experiencia sexualizada, afirmación a la que se le ha reconocido una gran originalidad, es preciso evocar en este contexto el punto de vista en el que se coloca el autor de Métamorphose de l'âme ses symboles cuando se remonta a la producción cultural del fuego entre los hindúes. La producción del fuego está ligada al simbolismo sexual: el divino Agni es el producto de la frotación de dos pedazos de madera (Purúravas y urvaci); un canto de Rigveda tiene el mismo simbolismo y también ritos culturales dan cuenta del paralelismo entre producción del fuego y sexualidad. Esta inclinación general es la que conduce a Jung a preguntarse si no existe una estrecha relación entre la creación del fuego y la sexualidad ${ }^{14}$.

14 Se puede mencionar el interés de Jung por llevar esta conexión hasta el nivel filológico buscando una analogía entre el pramantha hindú (madero masculino mediante cuya frotación se produce el fuego) y el Prometeo de los griegos, aunque le resulte dudosa. Véase Símbolos de transformación, especialmente el cap. III. 
El símbolo, aclara Jung, "no es ni una energía ni un semeion (signo); es la imagen de un contenido que en gran parte trasciende la conciencia" (Metamorphoses de l'ame 155). La fuente de Juvencio (Ícono del siglo XVII, Escuela de Constantinopla) y la figura 133 del Arbor philosophica en la que dicho árbol sale del hombre le permiten examinar el sentido maternal de agua en las mitologías y paralelamente el árbol de la vida, árbol genealógico, también presente en numerosos mitos con una simbólica propia. Siguiendo esta huella, no dudará Bachelard en señalar las múltiples perspectivas que se abren con los mitos: valores cósmicos, sociales y poéticos.

Desde esta óptica, los mitos sintetizan "múltiples fuerzas psíquicas. Todo mito es un drama humano condensado. Los mitos son otras ocasiones para estudiar esa función directa de simbolización" (Bachelard, "Préface au Symbolysme dans la mythologie Grecque" 12).

Y habrá que agregar que en el lenguaje de los mitos también podemos encontrar principios oníricos porque los símbolos se transmiten tan fácilmente es porque crecen sobre el terreno mismo de los sueños afirma en el examen de las imágenes del árbol, pues en relación con la imagen literaria hay un riesgo que define al soñador y es la posesión de un cogito por el cual crea su propio cosmos: "Yo sueño el mundo, por lo tanto el mundo existe como yo lo sueño”, dirá en La poética de la ensoñación (84).

Esta identificación es tan decisiva para la psicología de la imaginación material que constantemente Bachelard nos estará recordando que la imaginación es "la facultad de formar imágenes que sobrepasan la realidad, que cantan la realidad"; más aún, es la facultad de "deformar las imágenes suministradas por la percepción”, con lo cual quiere romper con la explicación común y corriente de los psicólogos clásicos que hacían ver la imaginación como "la secuencia de lo ya percibido o de lo ya vivido desde una relación causal” ${ }^{15}$.

15 El esquema según el cual para imaginar hay que ver primero es precisamente lo que él critica para suponer de manifiesto el carácter primitivo, "el carácter psíquicamente fundamental de la imaginación”, esto es, su función no derivada. Anotamos de paso que ya desde 1900 el tema de la imaginación creadora comienza a recibir una mayor atención. Por ejemplo, Théodule Ribot, aunque todavía no la disocia 
Es necesario, sin embargo, admitir que la tesis de que lo irreal domina al realismo de la imaginación está inspirada en proposiciones de los románticos alemanes que Bachelard hace suyas, por ejemplo, cuando nos remite inmediatamente a Tieck, quien veía en un paisaje la realización de un sueño a menudo soñado (El agua y los sueños 13). Otro tanto habría que decir de las frecuentes referencias al idealismo mágico de Novalis, y también a Rilke ${ }^{16}$, siempre en la perspectiva propia de encontrar los nexos entre la función de la poesía y lo imaginario, la superación de la realidad y la realidad que nos revela la imaginación creadora. Es ese libre juego de imágenes en movimiento lo que hace precisamente que la imaginación creadora imponga un devenir a todo lo que crea y se enriquezca con la imaginación dinámica.

\section{Metodología de la imagen literaria}

Un aspecto particularmente interesante de destacar en el estudio de la imagen literaria es la manera como son trabajados los textos poéticos, fuente de toda multiplicidad de imágenes o más bien colección de imágenes con las que se encuentra el lector. En efecto, Bachelard toma fragmentos de los textos poéticos, cita y comenta unos versos o algunas estrofas y luego los integra a una sola problemática por la cual busca ligar al poeta con cada uno de los cuatro tipos de imaginación. Pero la meditación sobre los textos no se reduce simplemente a la paráfrasis y al comentario para descifrar imágenes. Es también recreación de

completamente de la percepción, la define como "la facultad de pensar por analogía”. Los trabajos de Sartre (La imaginación, 1936, Lo imaginario, 1940) serán decisivos para la separación entre imaginación y percepción. Así, en la conclusión de Lo imaginario antes de definir la obra de arte como un irreal, Sartre postula como condición inicial para poder imaginar que la conciencia necesariamente "tenga la posibilidad de proponer una tesis de irrealidad" (Sartre, 137).

16 Sobre todo, en La terre et les rêveries de la volonté donde Novalis es citado a partir de un texto que deduce de la imaginación todas las otras facultades. Novalis, el poeta de "La pequeña flor azul", el de los valores imaginarios, el poeta del sueño primitivo para quien "La pequeña flor azul es roja" (El psicoanálisis del fuego 34). No podría pasar desapercibida la preocupación de Clémence Ramnoux por las citas que hace Bachelard de los poetas alemanes en alemán y francés, de Novalis y Rilke. Esto la lleva a preguntarse ¿en qué condiciones él aprendió las múltiples lenguas en las que cita a los poetas, como buen autodidacta, en el Liceo de Champagne? 
las imágenes con ensoñaciones personales para construir una poética que bien podría girar "alrededor de una sola imagen".

La ensoñación representa la materia prima para la obra literaria y es concebida como una "actividad onírica en la que subsiste un resplandor de conciencia. El soñador de ensoñación está presente en su ensoñación".

Se comprende entonces con qué fuerza cita, por ejemplo, un poema de Verlaine escrito en la prisión ("El cielo está, por encima del techo, tan azul, tan calmo") para luego agregar:

En la cárcel. ¿Quién está en la cárcel en sus horas de melancolía? En mi cuarto parisiense, lejos de mi tierra natal, arrastro la ensoñación verlainiana. Un cielo de otras épocas no existe sobre la ciudad de piedra. En mis memorias cantan las instancias musicales que Reinaldo Hahn escribió sobre los poemas de Verlaine. Todo un espesor de emociones, de ensueños, de recuerdos crece para mí sobre ese poema. Por encima - no por debajo, no en una vida que he vivido- no en la vida mal vivida de ese desdichado poeta. En sí misma, por sí misma, ¿la obra no ha dominado la vida, la obra no sido un perdón para aquel que la ha malvivido? En todo caso, en ese sentido el poema puede acumular ensoñaciones, sueños y recuerdos. (La poética de la ensoñación 22-23).

La circulación de imágenes emprendida en cada una de las obras consagrada a los elementos es bien significativa para apreciar el alcance de la facultad definida como "la fuerza productora de imágenes". El agua silenciosa y triste de Poe, la ofelización de las aguas tranquilas en Brujas, Jerjes azotando las aguas, el matrimonio de la luna con el agua, las aguas enamoradas, son imágenes en las que se reconoce fácilmente una poética tejida con el "poema corto", con fragmentos de poemas y yuxtaposición de versos de diferentes poemas como Éluard, Mallarmé y Valéry alrededor del tema Azul del cielo en El aire y los sueños.

Sin duda, este método guarda vínculos con una concepción de la poesía expresada en La intuición del instante: "La poesía es una metafísica instantánea. Ella debe dar, en un breve poema, una visión del universo y el secreto de un alma, un ser y cosas, todas a la vez" (51). 
Definición que marca el comienzo de la meditación sobre el "Instante poético y el instante metafísico" (1939) como complemento de una problemática ya inscrita en los planteamientos de Gastón Roupnel sobre el instante. No hay más que una realidad, el instante, enfatiza Bachelard en polémica con la filosofía bergsoniana de la duración. El tiempo vertical (no sujeto a la media) es el tiempo de la poesía, en oposición al tiempo como un horizontal, al tiempo del mundo, y por eso en la complejidad del instante poético no vacila en afirmar que este “conmueve, demuestra invita, consuela es sorprendente y familiar".

Como se ve, este concepto de poesía que produce, que crea su instante, "que construye ese instante complejo", juega un papel fundamental en la organización de una poética que al mismo tiempo que se ocupa del instante poético, le agrega a las imágenes de la ensoñación del poeta sus propias ensoñaciones. Porque para un soñador de palabras "la poesía es uno de los destinos de la palabra", "un reino del lenguaje", y que no exagera cuando afirma que la poesía es "la actividad pancalista de la voluntad" y describe el lenguaje poético en términos de "promoción del ser". Rilke celebra la manzana con los siguientes versos:

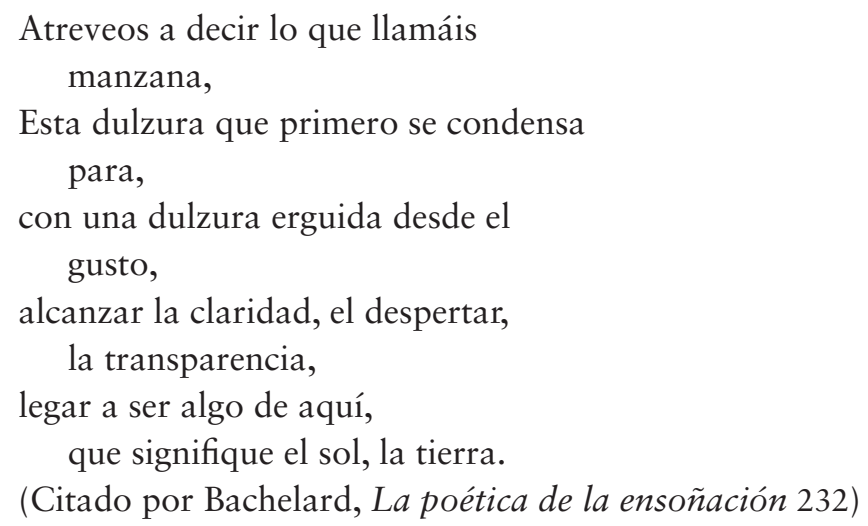

A lo cual Bachelard como poeta agrega:

La dulzura erguida desde el gusto concentra una dulzura del mundo. El fruto que tenemos en la mano da prueba de su madurez. Su madurez es transparente. Madurez, tiempo economizado 
para el bien de una hora. Hay muchas promesas en uno solo fruto que reúne el doble signo del cielo asoleado y de la tierra paciente. El jardín del poeta es un jardín fabuloso. Un pasado legendario abre mil voces a la ensoñación. Irradian avenidas de universo a partir del objeto celebrado. La manzana celebrada por el poeta es el centro de un cosmos, un cosmos en el que es bueno vivir, en donde estamos seguros de vivir. (La poética de la ensoñación 234-235)

En uno de los volúmenes dedicados a la tierra, La terre et les rêveries de la volonté, se reúnen imágenes tomadas del mundo del metal, de los minerales, de la madera, de la roca, de la pasta, de los cristales, de la piedra. De las imágenes de la petrificación deriva el complejo de Medusa y de la lucha contra la pesadez el complejo de Atlas. Bajo el signo de la preposición "contra" y de la dialéctica duro/blando Bachelard nos sitúa directamente en el campo de la materia terrestre caracterizándola por la resistencia permanente. En este sentido, la tierra favorece una "psicología del contra" generada por la adversidad que nos hace vivir la sustancia sólida: la cólera provocada contra el objeto por una materia como el granito, los excesos del deseo de cortar, el carácter agresivo de los útiles (un cuchillo) y la consiguiente violencia contra el universo, contras las cosas.

Las imágenes dinámicas de la imaginación terrestre están por consiguiente inspiradas en la lucha que anima al sujeto contra el mundo resistente y en los choques entre la voluntad de trabajo y la materia rebelde. Nos están mostrando que la imaginación desea penetrar la materia y que el trabajo sobre los objetos como necesidad de actuar sobre la materia es ya una especie de psicoanálisis natural. Si esto es así, el trabajo es siempre origen, ya que "recrea imaginativamente, por las imágenes materiales que lo animan, la materia misma que se opone a sus esfuerzos" ${ }^{17}$ (La terre et les rêveries de la volonté 31).

En la obra complementaria, La tierra y las ensoñaciones del reposo, coloca las imágenes bajo el signo de la preposición "dans" [en, dentro] y del modelo de reposo propio de las ensoñaciones de

17 De ahí que deteniéndose inmediatamente en el Homo Faber considere que la materia dura se nos revela como "una gran educadora de la voluntad" y como "reguladora de la dinamogenia del trabajo". Rasgos que ya se pueden apreciar en las páginas 
la intimidad material: la casa, el vientre, la gruta. Pero están también las imágenes dinámicas del movimiento torcido (la serpiente y la raíz) examinadas sobre todo desde la óptica de los arquetipos de Jung, ya que encuentran sus raíces en el más lejano inconsciente. Así, la gruta nos proporciona la idea de reposo, refugio, morada, mientras que el laberinto evoca una dimensión de angustia que es inconsciente, pero que se relaciona con la estrechez, la dificultad de movilidad y el cruce de caminos.

Queda ahora por examinar qué entiende por imagen, ya que constantemente utiliza el término y las fórmulas que en ciertos aspectos pueden llevar a una ambigüedad. Si bien es claro que la imagen literaria es el eje de las preocupaciones del filósofo por la imaginación activa y sobre esto sigue insistiendo en L'introduction à la poétique du Phénix. Sin embargo, Bachelard nos habla de la imagen primera (el árbol cósmico), de la imagen literaria pura (la serpiente), de la alondra, también, como una imagen literaria pura, de las imágenes “princeps" (la flor), de las imágenes fundamentales, de la ambivalencia de las imágenes (la oposición agua tranquila/agua violenta), del dualismo de la imagen (vida y muerte en la imagen de la llama), de la bi-imagen y de la imagen psicotrópica.

La alondra es el prototipo de una imagen literaria pura y de un romanticismo de la alegría. En efecto, ¿quién puede descubrir la alondra? Ciertamente no es el pintor. Sin embargo, el poeta la describe, la ve cuando la evoca: es Michelet, es Meredith, es Maurice Blanchard, pero su visión no es la de la realidad del mundo exterior, sino la de una pura imagen. La alondra es "un corpúsculo invisible al que acompaña una onda de alegría” (El aire y los sueños 109).

Una imagen literaria, pues, es por consiguiente aquella que toma toda su existencia de la literatura y se presta a una exaltación cósmica. Lo es igualmente la imagen de la piedra preciosa que se escribe, se describe, pero no se ve, y de la que el soñador con plena autonomía 
de las imágenes puede decir que "la esmeralda es un gran estanque de agua marchita" (La terre et les reveries de la volonte 322 ).

Hemos podido ver, al seguir la lectura que Bachelard hace de los textos literarios y míticos, que la imagen tiene una realidad propia, que la imagen poética se presenta en ruptura con un "ser antecedente", ya sea la percepción, la emoción, el pensamiento o el recuerdo. Es por esto que la noción de repercusión, resonancia, en el sentido de Minkowski, es la que nos puede ayudar a comprender mejor el verdadero ser de la imagen poética, su carácter incausado: "en la resonancia oímos el poema, en la repercusión lo hablamos, es nuestro" (La poética del espacio 14). Sobre esa base recurre a una fenomenología de la imagen en La poética del espacio y en La poética de la ensoñación en el sentido bien particular que quiere darle, esto es, como estudio del fenómeno de la imagen poética en el momento en que surge en la conciencia de un individuo. Este desplazamiento del psicoanálisis, que según él intelectualiza demasiado la imagen, a una fenomenología del alma que aspira a determinar el ser de la imagen, lo lleva a declarar que "la imagen surge en la conciencia como producto directo del corazón, del alma” (citado por Lescure, Un été avec Bachelard 58).

Si Pierre Reverdy definió la imagen como "una creación pura del espíritu que no puede nacer de una comparación sino de la aproximación de dos realidades más o menos alejadas" no es acaso esta definición la que le sirve de hilo conductor a la poética bachelardiana para afirmar que la imagen poética "no es el eco del pasado", que la imagen es siempre una promoción del ser, que la imagen poética es "una emergencia del lenguaje”. Porque precisamente ese carácter de emergencia de la imagen literaria implica que el poeta con la novedad de sus imágenes sea siempre origen del lenguaje. Y es mediante esa relación de la imagen con el lenguaje, con la palabra que es poesía, como Bachelard manteniéndose bien cerca de los surrealistas considera que la poesía es una liberación del espíritu ("la libération du psychisme par la poésie”), liberación en la que cree precisamente cuando señala que "en una poesía más liberada como el surrealismo, el lenguaje está en plena ramificación. Entonces el poema es un racimo de imágenes” (La terre et les rêveries de la volonté 7). 
La imagen poética nos "sitúa en el origen del ser hablante", "la expresión crea al ser”, “las palabras sueñan”, son expresiones bien significativas para una fenomenología ontológica y nos llevan a reconocer una vez más que el vocablo que mejor le conviene a la imaginación no es imagen, sino imaginario es lo dicho por el poeta. En este sentido, es por la imaginación como el hombre alcanza el ser, el bienestar y supera la condición humana, es decir, hace evidente su facultad de sobrehumanidad. Para la fenomenología de la imaginación, por consiguiente, el poema es un tejido de lo real y de lo irreal, "los poemas son realidades humanas" que se viven y por eso "un verdadero surrealismo" tiene que aceptar la imagen en todas sus funciones y proclamar con Artaud que lo que hace visible y tangible la realidad es la poesía misma. De este modo, en El derecho de soñar fácilmente puede establecer el vínculo de la poética con un sistema filosófico mediante la palabra: "Mediante una palabra se está seguro de encontrar un sistema filosófico... Ahora bien, escribir es reflexionar en las palabras, es oír las palabras con toda su resonancia" (187).

Es entonces sobre el terreno mismo del surrealismo como hay que ver la primacía otorgada a lo imaginario sobre lo real y la relación de la imagen con el deseo, bien explícita en los libros consagrados al agua y al aire. La dialéctica bachelardiana de la realidad como potencia de sueño y del sueño como potencia de la realidad nos hace pensar en la armonización postulada por André Breton entre sueño y realidad. La sobrerrealidad o "surrealidad" definida en el Primer manifiesto (1924) "como una especie de realidad absoluta" es a su vez una especie de conocimiento supremo de todas las dimensiones de lo real.

Es en la representación que Breton se hace de la poesía donde podemos encontrar la mejor justificación de su ambición de ser real. Pues la poesía revela el mundo de la surrealidad y este es considerado como real, único real, por el hecho de ser la síntesis del mundo imaginario y del mundo visible. La confianza de Breton en la poesía es como lo anota Ferdinand Alquié porque:

Ella le parece ontológica, vital, le parece que posee las claves de la libertad, que contiene el mensaje de la felicidad humana, y esto en la medida en que ella es el lenguaje original, el 
único lenguaje verdadero que expresa el ser y crea sus objetos.

(Philosophie du surrealisme 41)

La práctica de la poesía es para Breton no sólo un medio para conducirnos al mundo de lo maravilloso ("lo maravilloso es siempre bello [...] debemos decir que solamente lo maravilloso es bello"), sino también una manera de devolverle al lenguaje su verdadera vida y de romper con la visión cotidiana de los objetos en el marco de una insurrección contra "el imperio de la lógica" y los excesos de "la razón razonante".

Desrealizar el mundo implica una ruptura con un orden de relaciones lógicas que se pueden establecer entre los objetos y al mismo tiempo una modificación de la visión cotidiana de las cosas. Desrealizar el mundo es destruir ese orden, es desorganizar ese mundo de objetos y su correspondiente discurso a cambio de una forma diferente de representar la modificación de la imagen a través de objetos no convencionales. Todo ello es posible porque para Breton la imagen proviene de una conciencia imaginativa y tomada en la síntesis del sueño es una vía para el conocimiento de nosotros mismos. No vacila Maurice Nadeau en presentar al surrealismo más como un medio de conocimiento que como una escuela artística o una doctrina: exploración del inconsciente, lo maravilloso, el sueño, y simultáneamente afirmación de una serie de valores como la omnipotencia del inconsciente, la escritura automática, la destrucción de la lógica y "todo lo que impide al hombre vivir según su deseo".

Para Breton, lo que más cerca está de "la verdadera vida” son los encantos de la infancia porque, como dirá más tarde Bachelard, "la infancia no abandona nunca sus moradas nocturnas”. Esta convergencia no es extraña, dada la importancia que Bachelard le otorga a la infancia y la creencia en el poder del inconsciente constantemente asociadas a la idea de un psicoanálisis nuevo del que no logra desprenderse a pesar de la tentativa fenomenológica ${ }^{18}$, pero que, como se verá

18 Es, según su concepción, como hay que interpretar las numerosas declaraciones en las que Bachelard se vale de la fenomenología para explicar la imagen poética. Por ejemplo, fenomenología de lo redondo, del verbo habitar, del verbo salir (a través de las imágenes de las Melusinas alquímicas en La poética del espacio, y las imágenes de las sirenas en La tierra y las ensoñaciones del reposo (153). Recordemos también que ya en la introducción al Materialismo racional nos habla de una fenomenología 
más adelante, se justifica por el empleo del término y las constantes referencias a la doctrina de los arquetipos de C. G. Jung: "los arquetipos serán siempre orígenes de imágenes poderosas" (La poética de la ensoñación 190).

\section{La metáfora}

Imagen y metáfora constituyen en Bachelard un mismo centro de interés para la imaginación poética, pues a menudo nos está señalando que la imagen adquiere todo su sentido de las metáforas, que la metáfora en el lenguaje alquímico es origen de la imagen o incluso que las metáforas llegan a ser imágenes, lo cual ya plantea un problema de diferencia entre imagen y metáfora porque mientras en algunos análisis se mezclan para sugerir que la metáfora es un tipo de imagen, "una falsa imagen”, en otros, por el contrario, la diferencia se funda en lo que él denomina el valor fenomenológico, entendido en últimas, como una especie de ontología de la imagen. En este sentido, la metáfora, en cuanto es, no resiste un análisis fenomenológico que centre su significación solamente sobre las implicaciones del surgimiento de la imagen en la consciencia individual.

La imagen, al contrario de la metáfora, es "un fenómeno de ser", específico del ser hablante, es vida nueva y conciencia de creación, y en este sentido es susceptible de un estudio fenomenológico apoyando en el valor, por ejemplo, el valor de intimidad que proporcionan las imágenes del espacio interior dentro de una fenomenología de lo escondido (la casa, los cajones, el cofre). El espacio de la imaginación es desde luego el espacio vivido.

Ciertamente no hay en Bachelard una teoría de la metáfora, pero el término aparece frecuentemente en sus obras y no siempre refleja una misma acepción ni el sentido que le presta adquiere la misma intensidad, ya que en algunos momentos se refiere a ella de manera peyorativa como un peligro para la formación del espíritu científico

materialista y de una difenomenología de doble perspectiva; por una parte, tendría que ver con la consciencia misma, y por otra, una fenomenología asociada con "la sorda persistencia del inconsciente, la actividad nunca satisfecha de las ensoñaciones inconscientes" (36). 
(las metáforas seducen la razón) y en otros, la metáfora es parte de la esencia de un espíritu poético:

\begin{abstract}
Las metáforas no son simples idealizaciones que parten, como cohetes, para estallar en el cielo desplegando su insignificancia, sino que, al contrario, las metáforas se apelan y se coordinan más que las sensaciones, hasta el punto que un espíritu poético es pura y simplemente una sintaxis de metáforas. (El psicoanálisis del fuego 179)
\end{abstract}

Pero lo que sí es bien claro en sus estudios sobre la imaginación material es el poco interés por asumir la oposición entre sentido propio (original, primitivo) y sentido figurado, oposición básica en uno de los modelos de análisis de la metáfora, el sustantivo, modelo común a la poética y la retórica occidentales desde Aristóteles: los términos se pueden emplear en más de un sentido, el sentido propio o corriente inmediatamente dado en cada uno de nosotros y el que se desvía de él, el extraño (allotrios). La metáfora como "transposición del nombre de una cosa u otra" es una sustitución del término propio por el figurado, fundado en la relación de semejanza; de ahí que Aristóteles considere que para hacer buenas metáforas hay que conocer bien las relaciones de semejanza. Para Bachelard, la fuente de Juvencio es una metáfora en la que "no existe un sentido figurado" porque, de hecho, la fuente simboliza un perpetuo rejuvenecimiento, es regeneración y purificación, elíxir de vida alquímico.

Derrida ha hecho notar en su trabajo sobre la metáfora en el texto filosófico que lo que más interesa a Bachelard es el sistema de metáforas y no tanto el concepto mismo de metáfora. Sistema que se hace bien explícito en La llama de una vela y en cuanto al concepto mantiene el sentido ordinario y tradicional como una forma de desplazamiento. Las metáforas, afirma, "no son, a menudo, más que traslación de pensamientos, en un afán de expresarse mejor, de decir de otra manera la imagen" (10).

La metáfora como traslación de pensamientos, en una voluntad de expresarse mejor, está ligada al cogito de un soñador que la expresa, a un sujeto que la dice; y, a su vez, las metáforas en un destino común con las imágenes permiten acceder al ser, al ser que nosotros somos. 
Por eso exclama que "las metáforas son realidades y la realidad, puesto que es contemplada, es una metáfora de la dignidad humana" (La llama de una vela, 35).

La metáfora representa entonces la dimensión humana y cósmica de la obra literaria en la perspectiva del movimiento de la imaginación no solo por el lugar que le otorga en la exposición de las metáforas de la dureza (La terre et les rêveries de la volonté 63-73), sino también por el papel que le asigna en la vida de la imaginación. De ahí que señale a la manera de un imperativo que la vida de la imaginación depende del enriquecimiento de la imagen con la metáfora.

Al determinar el sistema de metáforas como metáforas axiomáticas, alquímicas, sadomasoquistas, metáforas mortales, metáforas de la dureza, ya se trate de un realismo o de un idealismo de la metáfora es claro que el adorno, la ostentación y la exuberancia son inherentes a la vida literaria y que esta se desarrolla ininterrumpidamente en el mundo de la metáfora (La tierra y las ensoñaciones del reposo 76).

En un primer sentido, en el contexto de una polémica con Bergson por el uso exagerado de metáforas ("los conceptos son cajones que sirven para clasificar los conocimientos”, decía Bergson), la metáfora es entendida como un medio de expresión, un accidente de la expresión, un simple medio fabricado, en oposición con la imagen. La imagen del ébano en Poe es el prototipo de una imagen literaria, raíz de ensoñaciones, emociones y transposiciones, tal como se puede apreciar al final de El aire y los sueños.

En un segundo sentido, el hecho de caracterizar la imagen poética por la creatividad del lenguaje al nivel de la palabra y la frase convierte a la metáfora en el soporte lingüístico de la imagen y de esta manera puede decirse que la imagen es introducida por la metáfora. Por eso destaca como una constante que "imaginar es ausentarse, es lanzarse hacia una vida nueva... Para experimentar de veras el papel dimaginador del lenguaje es preciso buscar pacientemente, respecto a todas las palabras, los deseos de alteración, de doble sentido, de metáfora" (El aire y los sueños 12).

Paralelamente en relación con la poesía el papel de la metáfora es primordial y nuclear: "La metáfora es el fenómeno del alma poética". 
Finalmente, entre las funciones del lenguaje está la de sugerir valores metafóricos, ya que "es por las metáforas, por la imaginación, como la realidad toma sus valores". Transportar a otros mundos, "significar otra cosa" y "hacer soñar de otro modo" convierten la metáfora en portadora de nuevas significaciones. De ahí la importancia de la vida metafórica para la terapia del sueño despierto de Desoille, método de exploración y psicoterapia que mediante imágenes inductoras (las cimas, los árboles) y metáforas de la ascensión conducía a formar un super-yo imaginante y favorecía el desbloqueo de los problemas efectivos.

Es sin duda imprescindible, también a propósito de la metáfora, hacer alusión a una tesis apenas mencionada a propósito del tema de la serpiente como una imagen tradicional, o imagen compleja (da la vida, pero también la muerte) que ha jugado un papel considerable en la imaginación literaria a la manera de un símbolo motor o arquetipo. Las mitologías naturales, afirma, se forman en el acto literario más sencillo: la metáfora (La tierra y las ensoñaciones del reposo 262). Pero ya en una obra anterior, El aire y los sueños, cuando se ocupa de los mitos relacionados con los árboles cosmogónicos, antropogónicos y fálicos, Bachelard encuentra que ciertos mitos se basan en los principios oníricos y que el árbol cosmológico es una imagen primera, imagen que "produce todas las otras imágenes".

Entre las metáforas axiomáticas distingue las de altura, de elevación, de profundidad, de rebajamiento, de caída; de ellas se puede decir que "nada las explica y lo explican todo". La denominación es bien curiosa pero quizás hay que entenderlas en el sentido de que son verdaderas metáforas que no necesitan de una demostración, son admitidas sin discusión y no requieren de un análisis especial para comprender cómo se presentan aun en la vida cotidiana. En esta dirección, en efecto, se imponen las metáforas de la caída ontológica, la caída moral y la caída imaginaria como convergencia en la verticalidad.

Las metáforas alquímicas. En la gran riqueza simbólica del lenguaje alquímico (recordemos la cuadratura del círculo y su poder simbólico en el opus alchymicum), Bachelard encuentra un sistema de valorizaciones afectivas propias del espíritu precientífico comprometido más con lo simbólico que con el conocimiento objetivo. El hecho de representar 
al oro por el sol y la plata por una media luna y que se designaran los nombres de los metales con los planetas (azogue = Mercurio; cobre $=$ Venus; tierra = Marte) se fundaba en una correspondencia mutua del mundo de abajo con el mundo de arriba o en la afirmación de la unidad armónica del mundo.

Para los alquimistas, "Mercurio" designaba varias cosas a la vez: sustancia química (Hg), el dios Mercurio (Hermes), el planeta Mercurio, y la "sustancia transformable"; como símbolo unificador era metal, pero también líquido, materia y también espíritu, frío y también caliente, de naturaleza femenina y también masculina. El hermafrodita típico es el Mercurio. Lo que los alquimistas querían simbolizar a través de esta doble naturaleza era la totalidad que une a los opuestos, la coincidencia oppositorum de Nicolás de Cusa. No ha dejado de señalar Jung esta explicación cuando ve a los alquimistas, como pone en evidencia, apoyándose en el simbolismo, la proyección de contenidos inconscientes o formas arquetípicas (La psicología de la transferencia 193-195).

La simbólica sexual y las lecciones de intimidad que el autor de La formación del espíritu científico encuentra en la alquimia nos ponen de manifiesto el vínculo entre fantasías y sueños, imágenes objetivas y deseos subjetivos. Aquí la metáfora se hace indispensable para comprender más claramente el proyecto de un psicoanálisis del conocimiento objetivo. En efecto, afirma el filósofo:

Las metáforas llevan siempre el signo del inconsciente: son sueños cuya causa ocasional es un objeto. Así, cuando el signo metafórico es el mismo signo de los deseos sexuales, estimamos que deben interpretarse las palabras en el sentido fuerte, en el sentido pleno, como una descarga de la libido. (229)

El alquimista llama al mercurio "flagelado y excavado" y desde una creencia en el mito de lo interior (todas las cosas, las sustancias ocultan algo interior) es portador de algo oculto. También desde otro obstáculo para el conocimiento científico, el mito de la digestión (“el cuerpo del hombre es un horno"), la idea de alimento en el espíritu precientífico es tan valorizada que, por analogía, la asimilación de los alimentos es extendida a los metales, a la tierra, al fuego: 
- El antimonio es un "lobo devorador". Los corrosivos devoran los metales.

- La tierra es un inmenso aparato digestivo: "La tierra tiene como sus entrañas sus vísceras, sus filtros, sus coladores".

- El fuego se alimenta como un servicio y es una especie de animal rapaz e insaciable. El concepto de alimento como una forma de valorización enraizada en el inconciente, rasgo característico del espíritu precientífico, nos lleva de nuevo al problema de los conceptos utilizados en la vida común y a la relación de equivalencia entre dos sustancias o al problema de la metáfora. Para no caer en la continuidad entre conocimiento común y conocimiento científico, lenguaje común y lenguaje científico, estas imágenes en nada son favorables al espíritu científico y más bien llevan a postular con mayor insistencia la necesidad de una ruptura, que nos atrevemos aproximar con la crítica de Spinoza al conocimiento vulgar en el Apéndice de la primera parte de la Ética: “Todas las nociones que el vulgar tiene la costumbre de utilizar para explicar la naturaleza no son más que maneras de imaginar y no revelan la naturaleza de ninguna cosa sino solamente la constitución de la imaginación” (II).

Los ejemplos del bestiario alquímico (lobo "devorador", “animal rapaz insaciable”) ilustran la relación de equivalencia entre dos sustancias ( $x$ es $y$ ), relación que va de lo abstracto a lo concreto y se funda justamente en la conjuración de la "violencia, la crueldad, la agresión y la rapidez del ataque".

Todas las otras metáforas alquímicas provienen del deseo de rejuvenecimiento, de las propiedades atribuidas a las piedras preciosas ("el zafiro y la esmeralda conducen a la castidad"), de las enfermedades de los minerales ("la herrumbre es una enfermedad del hierro"), de la fecundidad de las minas y de la sal ("la sal provoca fertilidad"). A todo esto, se añade que para el inconsciente toda mezcla es un matrimonio; Bachelard mismo parece comprobarlo cuando en sus lecciones de química los alumnos asociaban la reacción del ácido y de la base con lo masculino y lo femenino, respectivamente. 
La metáfora "las bodas alquímicas", tan fundamental entre los herméticos, se convierte frecuentemente en la matriz a partir de la cual se originan "las bodas de la piedra consigo misma", el matrimonio del sol y la luna, del rey y la reina, del azufre y el mercurio. De las propiedades atribuidas al azufre (el calor y la sequedad) y al mercurio (frialdad y humedad) y del hecho de relacionarlas simbólicamente con fuerzas creadoras de origen masculino, activas o pasivas, es preciso evocar aquí ante todo las metáforas que representan el "combate íntimo" de lo masculino y lo femenino en las instituciones alquímicas: el mercurio sufre el complejo de Edipo ("él es quien reconcilia a su padre y su madre desterrando su antigua enemistad, él es quien corta la cabeza al rey... para conquistar su reino";) están también las metáforas sadomasoquistas: el amor del ácido por la base a la que asesina y luego se suicida, la lucha del agua y la fuerza erótica del fuego.

Es a partir de esa química de la hostilidad como va a preguntarse a propósito del lirismo del herrero y de la artesanía metalúrgica: esa derrota repentina fácilmente pone en juego las grandes dialécticas del sadismo y del masoquismo. ¿Por quién toma partido usted? ¿Por el fuego o por el agua, por el principio viril o por el principio femenino? (T.R.V. 145) Así aparece que en la ensoñación alquímica actúan recíprocamente y, por así decirlo, se mediatizan mutuamente el animus y el anima en una especie de dialéctica de la que será tributaria la misma poética bachelardiana de la ensoñación. De hecho, el soñador y poeta multiplica las imágenes del fuego (el fuego íntimo), del agua, del aire y de la tierra reservándoles una forma de intimidad bien próxima a la de las imágenes alquímicas; es la metáfora por excelencia en la que fácilmente se deja reconocer la dualización dialéctica o, en términos de Starobinski, "el mito psicológico animus y anima”, dos potencialidades en las que hace reposar la ensoñación y la misma escritura del poema.

Es precisamente en el terreno de esta dualidad donde se asocian todos los rasgos que hacen que la ensoñación sea por esencia femenina. La feminidad de las palabras, los nombres femeninos de las flores (la rosa, la centáurea), las imágenes del agua no son otra cosa que evocaciones para volver a encontrar el vínculo entre la ensoñación y las palabras, una vía más para demostrar que el género de las palabras, lejos 
de cualquier azar, se compone en un solo tejido con la ensoñación. El reposo, la paz, la dulzura ponen su marca femenina a la ensoñación y explican nuestra afiliación al mundo, mientras que las construcciones del sueño se integran a los proyectos, las historias, los dramas propios del animus. por tanto, las imágenes femeninas están relacionadas con el arquetipo ánima que corresponde en Jung al "elemento femenino del X masculino". En cambio, las ensoñaciones en animus operan en la imagen del Fénix, Prometeo y Empédocles, concebidos como "seres dominantes" y además subordinados a un "animus que no acepta las dulzuras de anima" (Fragments 44).

\section{Imagen, símbolo y arquetipo}

Una de las características más evidentes de la inspiración bachelardiana es su posición mantenida con respecto al psicoanálisis, o, más precisamente quizás, la libre utilización y la ausencia de un tratamiento sistemático a lo largo de sus escritos sobre todo cuando intenta poner en práctica una herramienta que cabalga sobre dos opciones definitivas. En primer lugar, permite curar de la "afectividad" de las convicciones individuales y denunciar los “contratiempos” u obstáculos epistemológicos que se interponen al espíritu científico. Es gracias al psicoanálisis del conocimiento objetivo como se puede liberar al pensamiento de nuestras imágenes y de las convicciones profundas, de conceptos valorizados y de valores simbólicos presentes en el inconsciente.

Se puede decir que la conjunción de imágenes valoradas y de pensamiento simbólico corresponde a una mentalidad precientífica ${ }^{19}$ en constante oposición con lo específico de la actividad científica: el sentido del problema ("la ciencia consiste esencialmente en una proliferación de problemas”, afirma refiriéndose a Brunschvicg) y el encuentro de las teorías, los conceptos y los métodos en la producción de conocimiento.

Por otra parte, en relación con el orden imaginario, el psicoanálisis remite a los cuatro elementos de las cosmogonías tradicionales

19 Concepto que desempeñó un papel importante en el contexto cultural de los años treinta, luego de la orientación decisiva que le dio la etnología de Lévy-Bruhl al comparar la sociedad primitiva (mentalidad "prelógica") con la sociedad civilizada. 
vistos como los "operadores de imágenes" o ejes referenciales de la ensoñación. Shelley y Nietzsche por sus vínculos con la sustancia aérea son poetas ascensionales. El hecho de que en Shelley las imágenes sean un espacio de manifestación de la imaginación dinámica, porque giran alrededor del aire, el viento, el olor, la luz, explica que su poética esté construida sobre imágenes (recordemos la imagen de la isla suspendida y la imagen de Prometeo liberado) que son: “operaciones del espíritu humano en la medida en que nos aligeran, o nos levantan o nos elevan. No tienen sino un eje de referencia: el eje vertical" (57).

EL psiquismo aéreo del poeta inglés abre la vía para una confrontación con las imágenes que según Bachelard inspiraron la poética de Nietzsche, a quien identifica como el poeta vertical, el poeta de las cimas. La confrontación, emprendida en el capítulo V de la obra consagrada al aire, por lo demás bien interesante para seguir de cerca no solo el profundo parentesco entre los dos, sino también los contrastes paralelos, se apoya en un estudio minucioso de las poesías y pasajes del Así habló Zaratustra.

Son numerosos los textos en que las imágenes de Nietzsche son las cimas, los vientos, las nubes, el aire puro, el aire nuevo. La misma imagen de Zaratustra en lucha contra el viento nos hace sentir la síntesis del aire y la libertad y todo ese universo que lleva al símbolo de la verticalidad: "con el pensamiento en el viento" el caminar se vuelve un combate. De suerte que el pino al borde del abismo, el sendero de montaña, la pesca arriba (“¿algún hombre ha pescado jamás en las altas montañas?”), la barca que boga en el espacio, son imágenes y se podrían mencionar otras, que permiten detectar un mismo centro de gravitación de la poética nietzscheana. Más aún, son el testimonio más claro del complejo de la altura, sugerido desde la introducción a El aire y los sueños, y del que Nietzsche sería su representante.

De este modo, el destino aéreo, el psiquismo ascensional puesto aquí de manifiesto es esencial para la explicación de la creación poética en Nietzsche en la medida en que el elemento es el preludio de la imaginación material y de la imaginación dinámica. A este nivel es donde mejor podemos ver el sentido que quiere darle al psicoanálisis elementista y específicamente al psicoanálisis de la gravedad en 
Nietzsche. Sin embargo, desde que la imaginación material es caracterizada a partir de un elemento determinante (el agua pesada en Poe, el aire en Nietzsche, el fuego en Novalis), principio básico de la poética bachelardiana, ¿qué ha de entenderse entonces bajo la denominación de carácter a-causal de la imagen? La ambigüedad de la tesis de la irreductibilidad y la primitividad de las imágenes es aquí extremadamente marcada y choca con los propósitos metodológicos de reivindicar plenamente el acto creador de la imaginación.

En el prólogo a la obra de Patrick Mullahy, Edipo, mito y complejo, vemos cómo destaca la variedad de orientaciones que ha tomado la ciencia del inconciente y por consiguiente las dificultades que comporta una visión de conjunto de los temas fundamentales del psicoanálisis. Del breve recorrido por los desarrollos y mutaciones del psicoanálisis (Adler, Jung, Karen Horney, Sullivan), hay una afirmación bastante sugestiva, por cuanto nos lleva a abordar necesariamente la noción de símbolo y arquetipo en la medida en que son un terreno privilegiado para aclarar más su relación con el psicoanálisis. Es así como, según él, "para Jung los símbolos son realmente arquetipos".

Pero ¿qué significan el símbolo y el arquetipo invocados en su poética? Recordemos el propósito bien explícito de contribuir a enriquecer "por un carácter dinámico la noción de arquetipo" de Jung, en el momento mismo en que analiza las imágenes de la serpiente como arquetipo y símbolo motor, del Ouroboros como símbolo de eternidad, de la raíz y el vino como arquetipos del inconsciente. La serpiente es en nosotros un símbolo motor que se renueva constantemente como fuente de otras imágenes; el río serpentea, una cuerda es una serpiente; (La tierra y las ensoñaciones del reposo 293) y se la puede imaginar desde la dialéctica del bien y del mal, la vida y la muerte, como recta o redonda.

La confrontación con Jung se impone, porque desde que lo descubre no deja de afirmar el dinamismo de las imágenes. Es una adquisición tan definitiva de su pensamiento que se puede decir que para hablar verdaderamente de imaginación en la perspectiva de Bachelard es imposible separarla de la ensoñación que la dinamiza. Es esta concepción energética de la imaginación un punto decisivo de aproximación 
a la tesis junguiana de los arquetipos como reguladores de la actividad creadora ${ }^{20}$.

Afirma Jung:

Hay ciertas condiciones colectivas que existiendo en el inconsciente actúan como reguladoras y estimulantes de la actividad de la imaginación creadora y provocan las correspondientes formulaciones... Ellas se comportan exactamente como los motores de los sueños y es por esto que la imaginación activa, nombre que di a este método, reemplaza inclusive a los sueños hasta en cierto punto. (Les racines de la conscience 526)

\section{Lo colectivo se identifica con lo universal y se opone a lo individual o personal. Pero lo que en fin de cuentas está en juego no es tanto que}

20 El término "arquetipo" reviste varias acepciones y son múltiples los ejemplos con los que Jung quiso ilustrarlo (la cuaternidad, el círculo, la quaternio nuptial, anima/ animus, el árbol, el mito del héroe, el divino niño, el niño huérfano, el niño Dios) muy particularmente en relación con el simbolismo de la alquimia. Para un desarrollo histórico bien detallado del concepto de arquetipo en Jung, nos permitimos remitir a los excelentes trabajos de Jolamde Jacobi, Complex Archetype, Symbol y The Psychology of C. G. Jung. El término utilizado corrientemente por Jung desde 1919 es tomado del Corpus hermeticum de Dionisio el Areopagita (Jacobi, Complex, Archetype, Symbol, p. 34). En Les racines de la Conscience, precisa Jung que la expresión arquetipo ya se encuentra en Filón de Alejandría cuando se refiere al imago Deo en el hombre. En Irineo (cuando dice: "Mundi fabricator non a semetipso fecit haec, sed de alienis archetypes transtulit"), se encuentra en el Corpus Hermeticum (Dios es llamado la luz arquetipo) y en Dionisio el Areopagita (los arquetipos inmateriales).

"Archetypus" es una perífrasis explicativa para el eidos platónico (Les racines de la conscience 15). Es una estructura innata que le permite a un contenido expresarse en imágenes, "es una fuerza", es un modelo de comportamiento innato.

"Son elementos estructurales de carácter divino de la psique; poseen una cierta independencia y una energía específica gracias a la cual atraer los contenidos de conciencia que les convienen" (Métamorphoses de l'âme et ses symboles 386).

"Son imágenes originales simbólicas a partir de las cuales se edificó y diferenció el espíritu humano" (La guérison psychologique 95).

"La teoría de la alquimia, como creo haberlo demostrado, en lo esencial no es más que una proyección de contenidos inconscientes, es decir, de esas formas arquetípicas propias de todas las creaciones imaginarias en estado puro, tal como las encontramos en los mitos y cuentos, en los sueños, visiones y fantasmas de los individuos" (Psychologie du transfert 195). 
los arquetipos sean los contenidos del inconsciente y encuentren su expresión a través de los mitos, folklore, cuentos o leyendas, sino más bien la afirmación del dinamismo de las imágenes arquetípicas, como se deduce de L'introduction à l'essence de la mythologie y Psychologie de l'inconscient.

El inconsciente es para Jung la matriz original de la fantasía creadora y de los símbolos. Los símbolos tienen por base el arquetipo inconsciente y juegan un papel en la función trascendente o conciliadora de los contrarios (función conciliadora entre la razón y el sentimiento, la realidad y la irrealidad). El símbolo, afirma, "no es una alegoría ni un sémeion (signo); es la imagen de un contenido que, en gran parte, trasciende la conciencia” (Jung, Métamorphoses de l'âme 155).

Y aquí mismo precisa que los símbolos funcionan como transformadores en el sentido de que "transfieren la libido de una forma inferior a una superior" (libido entendida como energía psíquica.

La función de los símbolos (la cruz en el arte cristiano; la mandala como representación de la totalidad psíquica; la ciudad, la madera, el agua, como símbolos maternos) presente en objetos, números o imágenes le imprime a estos una serie de cualidades que modifican el significado común y corriente de la vida cotidiana. Hay en ellos una especie de vaguedad y nos están indicando una realidad desconocida u oculta para nosotros. Es así como para precisar la naturaleza del símbolo afirma que "una palabra o una imagen es simbólica cuando representa algo más que un significado inmediato y obvio" (Jung, El hombre y sus simbolos 20).

“Luego todo simboliza”. Es una conclusión a que llega Bachelard después de examinar la simbólica de la casa, los símbolos propios de la casa (el sótano como símbolo de la caverna, la buhardilla como símbolo del nido; las escaleras y los recuerdos imperecederos, etc.) y que se convierte en un principio para el análisis de la imaginación literaria. El árbol y el agua son símbolos maternos; Ofelia es un símbolo del suicidio humano; en las imágenes aéreas la altura es el símbolo en el que se unen el deseo de crecer y de volar; la barca de Caronte es el símbolo de la desgracia humana; el fénix es el símbolo de una eternidad que vive. Lo que caracteriza al símbolo no es acaso, se pregunta, "una relación esencial entre dos significaciones: ¿un sentido manifiesto y un 
sentido oculto?". La esencia del símbolo consiste por tanto en "sugerir un más allá de su expresión” y sería contradictorio entonces tratar de determinar en un símbolo su sentido inmediato.

Estas precisiones contenidas en el Prefacio a la obra de Paul Diel, Le symbolisme dans la mythologie grècque, hacen ver la necesidad de afirmar la autonomía del símbolo, su múltiple interpretación y el desplazamiento de un "centro fijo" o único de significación por lo general sexual. Es esta diferencia la que quiere establecer con el psicoanálisis clásico que frecuentemente se ha limitado al "conocimiento de los símbolos como si estos fueran conceptos". (Bachelard, El aire y los sueños 30). Por otra parte, es sobre la perspectiva simbólica como el estudio de los mitos adquiere un valor particularmente importante para un psicoanálisis cósmico. El simbolismo, para retomar uno de sus términos, "coordina” los valores míticos y los valores cósmicos. En la medida en que los mitos se nos presentan como "ocasiones" para estudiar la función de simbolización, su estudio nos aporta indicaciones sobre las múltiples fuerzas psíquicas en acción. (6).

No vacila el filósofo Michel Serres en calificar a Bachelard como el último de los simbolistas y el último de los psicoanalistas que reemplaza la relación inconsciente-cuerpo por la de inconsciente-naturaleza. Al registrar los cambios operados en relación con los símbolos del siglo pasado sobre Apolo, Dionisos, Ariadna, Zaratustra, Edipo, afirma:

Vemos que en Bachelard, tierra, fuego, aire y agua reemplazaron a Apolo o a Edipo, que el arquetipo-elemento reemplaza al arquetipo-héroe; y si Empédocles u Ofelia a veces aparecen bajo su pluma es de una manera subordinada: Empédocles ya no es más que una especie del género agua. (Serres, Hermès ou la Comunication 24)

\section{Conclusión}

Es un lugar común entre los expositores del pensamiento de Bachelard plantearse como una especie de enigma el problema de la unidad o la dualidad de su obra. Así, para Dagognet, por ejemplo, ciencia y poesía surgen de una misma concepción de la energía que engloba al mismo tiempo las tesis científicas y estéticas. El ritmoanálisis como equilibrio 
del "doble movimiento del pensamiento" rige la poesía y la ciencia, lo cual equivale a afirmar que reposan sobre el ritmo vibratorio, la vida rítmica de instantes e intervalos en oposición a lo inerte y continuo. Por consiguiente, la discontinuidad juega sobre los dos planos si se quiere tener el derecho de trabajar la materia, la pluralidad de materias diferentes, y acceder a la poesía como una fuerza de la naturaleza.

Otro argumento es que hacia 1940 Bachelard quiso acentuar su rechazo al realismo con La filosofía del no y Lautréamont comprometiendo en ese mismo movimiento a la ciencia y la poesía. La poesía no representa nada ("Lautréamont rompe las imágenes naturales, reemplaza las formas por las funciones, en fin, crea un lenguaje", subraya rápidamente Dagognet) y, paralelamente, la ciencia ya no es la ciencia de nuestro mundo, al que trataría de representar, sino más bien de verificar y es por tanto la razón la que organiza la materia. Si nada nos es dado inmediatamente, entonces la ciencia contemporánea ya no puede ser de hechos, sino producción de efectos. A estos argumentos habría que agregar que, si bien unos mismos intereses confluyen en dos campos netamente polarizados, el del intelecto y el de la imaginación, con condiciones bien específicas cada uno (las condiciones de la ensoñación y las del pensamiento no son las mismas), sin embargo, creemos que la tesis unitaria plantea mayores dificultades, ya que los mismos argumentos que conducen a una aproximación entre lo imaginario y lo racional pueden servir para suponer una tajante oposición. Otro tanto habría que decir de los planteamientos de Margolin en favor de un pensamiento unitario.

Si hay que volver sobre las dos vertientes que configuran el día y la noche de Bachelard, conviene instalarnos en la tesis bastante sugestiva de F. Pire, de una filosofía "creacionista" puesta en obra para dar cabida a todas las tendencias del espíritu humano. Lo cual nos permitiría comprender que haya insistido siempre a la vez en que la ciencia es un "esfuerzo prodigioso del espíritu" por crear un mundo bajo el impulso de la razón y que la imagen es una construcción del espíritu. Desde esta óptica estaría continuando una de las corrientes filosóficas más destacadas en Francia a fines del siglo XIX, el espiritualismo, ya sea a la manera de Victor Cousin o de Jouffroy, para quien la poesía, la religión y la filosofía brotan de un mismo sentimiento. 
"Espíritu científico" es una noción en la que se inspiró su epistemología y le marcó por tanto un itinerario bien preciso que ya hemos encontrado en toda su caracterización. Y en la medida en que es tomada como hilo conductor que explica el desarrollo del saber científico, constantemente le está planteando la exigencia de renovación y permanente rectificación de los conceptos y las teorías.

Hay un NES (Nuevo Espíritu Científico) que se contrapone a un AEs (Antiguo Espíritu Científico) porque lo rectifica y se constituye, con nuevos conocimientos, en valor absoluto. El espíritu científico es, en este esquema, dice Poirier, "ese arte implícito de pensar y de comprender, esa inteligencia creadora”. Afirmación bien reveladora de esa otra dimensión tan esencial al espíritu científico como es la variación, "el ensanchamiento" de los marcos del conocimiento que hace que a partir de Galileo no se pueda pensar como antes, por ejemplo, con Aristóteles en su explicación del movimiento sin tener en cuenta esa gran diferencia cualitativa que se establece entre el antes y el después. Pero también se puede pensar, dada la naturaleza tan subjetiva de los obstáculos en el proceso del conocimiento, que dicha noción queda inserta en una psicología del espíritu científico o más bien, como sugiere O. Roy, el espíritu científico es el espíritu del científico que Bachelard quiere rescatar mediante un proceso pedagógico.

Es necesario anotar también que la puesta en paralelo de la producción científica y la producción poética bajo el signo de un valor común, el valor de enriquecimiento o de novedad, de invención de vida nueva y de nuevos sentidos con la imagen poética, nos sitúa en el corazón mismo de una filosofía creacionista que hace de la razón y de la imaginación los motores de la actividad humana. Pero, yendo un poco más lejos, se podría ver aquí la expresión de un nuevo humanismo en el que el hombre es exaltado en una doble dimensión: es un animal de razón que crea un mundo a imagen de ella, y también un animal que imagina, imaginante y fundamentalmente soñador... Habría que meditar sobre los componentes de este díptico:

1. Bachelard cree caracterizar al hombre racionalista, el diurno, por una actividad de pensamiento que siempre recomienza, aun cada día, esto es, por el mérito de poner a trabajar el 
pensamiento concebido como una fuerza y no como una sustancia.

2. La imaginación es la máxima facultad hominizante.

3. En el hombre literario se condensan la meditación y la expresión, el ensueño y el pensamiento.

En definitiva, lo que aparece muy claramente en la fusión de estos dos campos que constituyen los pilares de la obra bachelardiana es una voluntad de comprender lo que nuestro autor designó con el nombre de "complejo de Prometeo". Cada uno "tiene su Prometeo", exclama al final de su vida en el inédito que había proyectado sobre una Poética del fuego. La imagen del héroe mitológico que roba el fuego del cielo para entregarlo a los humanos hay que captarla bajo el signo de "una actividad psíquica que consolida y dinamiza la vida del espíritu”. Es el símbolo de la vida intelectual en el que él mismo colocó la necesidad de superar nuestra naturaleza y el deseo de saber cada vez más mediante un proceso de actualización de la cultura: "Parece que en todo esfuerzo de cultura uno es el Prometeo de sí mismo".

Quizás entendemos mejor aquí por qué su epistemología, además de vigilante, crítica, aparece abierta a la discusión del saber dentro del campo cultural, dentro de los valores de cultura y por qué su pensamiento hay que asumirlo como una totalidad de dos actividades complementarias, la epistemología y la poética.

Es esta imagen la que hemos querido destacar en quien se definió como un hacedor de libros y un hombre de lectura o, como lo recuerda su hija Suzanne, como un eterno escolar a quien le gustaba aprender.

\section{Obras citadas}

Alquié, Ferdinand. Philosophie du surrealisme. Flammarion, 1955.

Danchin, Laurent y Rivière, Philippe. Linguistique et culture nouvelle. Éditions Universitaires, 1971.

Descombes, Vincent. Lo mismo y lo otro. Cuarenta y cinco años de filosofía francesa (1933-1978). Cátedra, 1979.

Descartes, Rene. Los principios de la filosofía. Alianza, 1995.

Bachelard, Gaston. El aire y los sueños. Fondo de Cultura Económica, 1958. 
Bachelard, Gaston. El agua y los sueños: ensayo sobre la imaginación de la materia. Fondo de Cultura Económica, 1958.

Bachelard, Gaston. El compromiso racionalista. Siglo Veintiuno, 1973.

Bachelard, Gaston. El derecho de soñar. Fondo de Cultura Económica, 1985.

Bachelard, Gaston. El materialismo racional. Paidós, 1976.

Bachelard, Gaston. El psicoanálisis del fuego. Alianza, 1966.

Bachelard, Gaston. Étude sur l'évolution d'un problème de physique. La propagation thermique dans les solides. Vrin, 1927.

Bachelard, Gaston. Études ( Noumène et microphysique », « La critique du concept de frontière épistémologique », " Idéalisme discursif », « Lumière et substance » et « Le monde comme caprice et miniature »), Vrin, 1972.

Bachelard, Gaston. Fragments d'une poétique du feu. Presses Universitaires de France, 1988.

Bachelard, Gaston. La actividad racionalista de la física contemporánea. Siglo Veinte, 1975.

Bachelard, Gaston. La dialéctica de la duración. Villalar, 1978.

Bachelard, Gaston. La formación del espiritu científico. Siglo Veintiuno, 1987.

Bachelard, Gaston. La filosofía del no: ensayo de una filosofía del nuevo espíritu científico. Amorrortu, 1973.

Bachelard, Gaston. La intuición del instante. Fondo de Cultura Económica, 1986.

Bachelard, Gaston. La llama de una vela. Monte Ávila, 1975.

Bachelard, Gaston. La tierra y las ensoñaciones del reposo. Fondo de Cultura Económica, 2006.

Bachelard, Gaston. La terre et les rêveries de la volonté. Jose Corti, 1945.

Bachelard, Gaston. La poética del espacio. Fondo de Cultura Económica, 1965.

Bachelard, Gaston. La poética de la ensoñación. Fondo de Cultura Económica, 1982.

Bachelard, Gaston. La valeur inductive de la relativité. Vrin, 2014.

Bachelard, Gaston. Le Pluralisme cohérent de la chimie moderne. Vrin, 1929.

Jacobi, Jolande. Complex archetype, symbol in the psychology of C.G. Jung. Psychology Press, 1999.

Jacobi, Jolande. The Psychology of C.G. Jung. Yale University Press, 1973.

Jung, Carl. El hombre y sus símbolos. Paidós, 1995.

Jung, Carl. Dialéctica del yo y del inconsciente.

Jung, Carl. Psicología y alquimia. Trotta, 2005.

Jung, Carl. Métamorphose de l'âme et ses symboles. Presses Universitaires de France, 2014. 
Jung, Carl. Les racines de la conscience. Presses Universitaires de France, 1995.

Jung, Carl. La guérison psychologique. Éditions Georg, 1984.

Jung, Carl. Psychologie du transfert. Albin Michel, 1980.

Jung, Carl. Psychologie de l'inconscient. Fayard, 1996.

Jung, Carl. L'introduction à l'essence de la mythologie. Payot, 2001.

Koyré, Alexandre. Estudios galileanos. Siglo Veintiuno, 1980.

Koyré, Alexandre. Estudios de historia del pensamiento científico. Siglo Veintiuno, 1985.

Lautréamont. Los cantos de Maldoror. Pre-Textos, 2000.

Lescure, Jean. Un été avec Bachelard. Nouvelle Édition, 1983.

Mullahy, Patrick. Edipo, mito y complejo. El Ateneo, 1953.

Sartre, Jean-Paul. Lo imaginario: psicología fenomenológica de la imaginación. Losada, 1982.

Sartre, Jean-Paul. La imaginación. Sarpe, 1984.

Spinoza, Baruch. Ética demostrada según el orden geométrico. Acervo Cultural, 1977.

Spinoza, Baruch. Tratado de la reforma del entendimiento. Alianza, 1988.

Spinoza, Baruch. "Préface au Symbolisme dans la mythologie grecque”. Diel, Paul. Le symbolisme dans la mythologie grecque. Payot, 2002.

Serres, Michel. Hermès ou la Comunication. Minuit, 1968. 


\section{Los obstáculos epistemológicos en la ciencia moderna ${ }^{21}$}

Una de las corrientes epistemológicas que han ejercido en el pensamiento contemporáneo una influencia considerable es la inaugurada por Gaston Bachelard hacia 1928. En efecto, con la tesis de que "el hecho científico es construido", Bachelard designa a la vez un aspecto importante y real para la historia del pensamiento científico y una actitud vigilante frente a las imágenes, las metáforas y todo lo que pueda interponerse como netamente subjetivo en el proceso del conocimiento científico. Un postulado de su epistemología lo constituye la afirmación del conocimiento como movimiento y como esfuerzo continuo de creación. "El acto de conocimiento no es un acto pleno", se lee desde las primeras páginas de la tesis doctoral Essai sur la connaissance approchée, en un intento por dejar establecido que el conocimiento

21 Publicado en Epistemología y filosofía de la ciencia. Fondo de publicaciones, Universidad del Atlántico, 1988. 
científico es "aproximado" y hay que purificarlo de cualquier forma de subjetividad y aniquilosamente en lo cotidiano.

La ciencia se caracteriza por la producción, es por esencia una producción y no una repetición de lo que sucede en la experiencia cotidiana. Un conocimiento aproximado no es un conocimiento aproximativo, sino un conocimiento que constantemente se está aproximando al objeto mediante rectificaciones propias de esa actividad concebida como "una evolución del espíritu". Al conocimiento científico, como aproximado, le corresponde, en consecuencia, una filosofía abierta y pluralista, en alerta para "seguir de cerca las modificaciones profundas del conocimiento científico" (La actividad racionalista de la física contemporánea 45). Ahora bien, si la ciencia es creación continua, es evolución de espíritu, es un modo de producción, es creadora de realidad, entonces ya no se la puede concebir como una lección de cosas y esto implica que lo real ya no es lo inmediatamente dado (lo real como algo existente fuera del pensamiento), sino que se define en relación con la razón.

Si se tratara de enumerar los aportes fundamentales que Bachelard le hace a la epistemología, bien podemos, a nuestro juicio, señalar los siguientes: la formación histórica de los conceptos, la noción de obstáculos epistemológicos y la ruptura. Los conceptos en su formación tienen una historia y unas condiciones de emergencia que van desde su aparición, los primeros sentidos, hasta las etapas de madurez y las cargas afectivas. En otras palabras, se puede hablar de una tarea de dialectizar los conceptos tal como aparece en la Filosofía del no con el concepto de masa, examinado en sus diferentes niveles: desde el realismo ingenuo hasta el racionalismo discursivo; examen que muestra en todo su recorrido una separación cada vez mayor del conocimiento común.

Cuando se considera el hecho científico como una producción del espíritu humano se comprende el interés por explorar y determinar las fuerzas psíquicas que están interviniendo en dicha actividad. Esta tarea es propia de lo que él denominó psicoanálisis del conocimiento objetivo, o sea, la indagación por la acción de valores inconscientes en la base misma del conocimiento empírico y científico. El psicoanálisis que profesa es un método para dar cuenta del progreso de las ciencias y de los diversos estados de desarrollo por los que pasan. Si las ciencias son racionalidades progresivas que en su dinámica propia están 
descalificando el conocimiento común, que tiene un pasado, "un pasado reformado", es preciso poner de manifiesto la fuente de donde brotan las convicciones subjetivas, las imágenes y las representaciones simbólicas en la relación sujeto-objeto. Se trata de los obstáculos epistemológicos. La experiencia básica, el conocimiento general, el obstáculo verbal, el conocimiento cuantitativo. Es esta búsqueda de condiciones psicológicas del progreso científico lo que nos hace pensar en una problemática bien paralela a la del autor de la teoría de los ídolos, cuando se propuso indagar por las causas del error, o más exactamente, por "las fuentes psicológicas”, según Cassirer. Así como para Bacon es preciso armarse de un método que pueda pacificar la mente de toda clase de representaciones imaginarias o de fantasmas o prejuicios, Bachelard advierte también la necesidad de una "catarsis intelectual o afectiva" que pueda purgar nuestro intelecto de imágenes, representaciones simbólicas y convicciones individuales.

La noción "obstáculo", obtenida de la función que desempeñan los "contrapensamientos" en el proceso mismo de formación del pensamiento científico, se puede seguir de cerca en La formación del espíritu científico, El materialismo racional (consagrada al desarrollo histórico de la química) y Psicoanálisis del fuego. Como característica común o fundamento común a todos ellos es preciso indicar la subjetividad o el a priori subjetivo de las valoraciones, y la satisfacción fácil e inmediata de la curiosidad. Son, como lo ha visto Michel Serres, una especie de vicios del pensamiento o pecados capitales de la no ciencia (orgullo, avaricia, lujuria, gula) en los que salta a la vista la ausencia de crítica y el empirismo inmediato. Su variedad es examinada con numerosos detalles y ejemplos en La formación del espíritu científico. Ellas son: la experiencia básica, el conocimiento objetivo, el obstáculo verbal, el conocimiento unitario y pragmático, el obstáculo sustancialista, el realismo, el obstáculo animista, el mito de la digestión, el obstáculo constituido por la libido, y los obstáculos del conocimiento cuantitativo. Sin necesidad de remontarnos a cada uno de ellos, es preciso señalar una exigencia elemental que Bachelard hace preceder al análisis de cada uno: el rechazo de la opinión. En efecto, si la ciencia se concibe como "una voluntad de razón”, "una voluntad de saber”, el primer obstáculo que ella debe superar es la opinión, ya que esta "no piensa" 
y lo único que pone de manifiesto es esa incapacidad para plantearse problemas, lo cual ya es un indicio de que no puede aportarnos más de lo que nos aporta el sentido común. Por el contrario, el sentido del problema es ya un acto enraizado profundamente en el movimiento mismo de la ciencia concebida como "conciencia creativa".

Detengámonos en el obstáculo que surge del lenguaje: el verbal. Los ejemplos son bien ilustrativos (la esponja, la botella de Leyde) y suficientes para dar a entender las diferencias que se presentan entre las significaciones del lenguaje usual y las del lenguaje científico y por consiguiente la discontinuidad entre ambos. A las palabras hay que situarlas en su significación científica: el concepto de capacidad "eléctrica" hay que desligarlo del uso corriente de capacidad "del lenguaje" común. Otro tanto habría que pensar de la palabra "corpúsculo", entendido según la intuición del conocimiento común como un "cuerpo pequeñito" en oposición a lo que la física contemporánea concibe como tal, esto es, ni como fragmento de una sustancia ni con dimensiones ni formas asignables. Es, por tanto, el abuso con las palabras, las trampas que puede tener el lenguaje y el conflicto de las significaciones lo que lleva a separar netamente, en esta epistemología, lenguaje científico o "neolenguaje" y el lenguaje común, y concepto científico y concepto vulgar. El concepto científico nos dice: es "una verdadera emergencia del conocimiento" (El materialismo racional 13). Es claro, entonces, que plantee tanto una actividad de vigilancia como de rechazo de las significaciones del lenguaje común y que paralelamente insista en la necesidad de ir a la formación de los conceptos, ya que "la palabra no es el concepto". El asombro por el descubrimiento de la botella de Leyde estuvo marcado por el peso de la palabra "botella", del lenguaje común, pero inmediatamente agrega: "la botella de Leyde no es una botella, no tiene absolutamente ninguna de las funciones de una botella" (El racionalismo aplicado 46). Es también este aspecto el que constantemente puntualiza Canguilhem cuando afirma que "ciertamente las palabras no son los conceptos que ellas movilizan”. El lenguaje científico se podrá caracterizar, dirá Bachelard, por "una permanente revolución semántica", por la cual se hace evidente el desfase entre la subsistencia de las palabras y las variaciones de los conceptos. 
Junto a la pedagogía de la razón o conversión de intereses en la razón, encontramos en Bachelard fundamentalmente al educador o, más precisamente, al pedagogo que constantemente nos está recordando que la ciencia es "una escuela permanente" y que el dualismo profesor-alumno es una constante dialéctica entre el racionalismo enseñante y el racionalismo enseñado, en contravía con la idea de adaptación a una determinada forma de sociedad, a una razón ya constituida un principio de autoridad.

Una de las pedagogías más atacadas fue la del "ver para comprender”, pedagogía completamente enraizada en la tradición aristotélica, según la cual, entre todos los sentidos, "es la vista la que nos hace conocer más” (Metafísica I). La enseñanza de las ciencias no puede reducirse a comparaciones y fáciles asociaciones que buscan hacer más inteligible el fenómeno. Por ejemplo, como procede María Montessori en sus lecciones de química, acudiendo a imágenes que más bien contribuyen a una forma de retardo del adolescente. Estas imágenes son satisfacciones baratas a las que hay que contraponerles "la penumbra de las dificultades" propias del conocimiento científico. Es esto lo que lleva a afirmar que "la claridad es a veces una seducción que cobra víctimas en las filas profesorales" (El materialismo racional 95). Este ideal pedagógico choca directamente con la idea de que la ciencia ya no puede ser una lección de cosas ni tampoco la enseñanza de la experiencia cotidiana. La ciencia, nos lo repite una y otra vez, "no es el pleonasmo de la experiencia" (El racionalismo aplicado 38). Frente al laboratorio, a los niños no se les debe enseñar cómo se hace un experimento, sino ante todo es preciso llevarlos a comprender y construir el conocimiento, es decir, estimulando una voluntad de saber o complejo de Prometeo. De ahí que se apoye en los trabajos del conde de Korzybski para afirmar que "el niño nace con un cerebro inconcluso y no con un cerebro desocupado... La sociedad concluye realmente el cerebro del niño; lo concluye mediante el lenguaje, la instrucción, por el adiestramiento" (La filosofía del no 106).

No hay ciencia sino mediante una escuela "permanente", es un postulado que plantea la necesidad de una formación permanente en el educador, dado el movimiento mismo de la ciencia. Por esto resulta imposible "educar por simple referencia a un pasado de educación. 
El maestro debe aprender enseñando y fuera de su enseñanza” (107). Si no es así, él mismo contribuye a institucionalizar una práctica muy común entre nosotros, de enseñar desarrollando lo conocido o de repetir cada año su saber a la manera de un pedagogo aristotélico firmemente aferrado al principio de identidad. ¡Es el alma profesoral!

“Todo lo que es fácil de enseñar es inexacto". Es un aforismo que pone de manifiesto la actitud deplorable del pedagogo positivista seriamente empeñado en adoptar métodos de comprensión que más bien contribuyen a una parálisis del pensamiento, pues si no se inquieta la razón se bloquea esa gran capacidad de cada individuo para construir en cuanto “organismo abierto". ¿De qué manera, se pregunta Bachelard, podría ayudar a la construcción del conocimiento la imagen del átomo planetario o la del átomo-sol de Raspail? Quizás convenga recordar, en este contexto, la crítica a la omnisciencia de los padres, al saber y al poder que automáticamente instalan un dogmatismo negador de la cultura, dogmatismo que por eso mismo se convierte en profético. Es la realización del complejo de Casandra que, apoyado en experiencias de la vida, hacen prever el futuro de la vida misma.

Finalmente, con una referencia a Balzac en La formación del espíritu científico, nuestro epistemólogo nos recuerda la condición de pedagogos y el dilema de enseñar solamente repitiendo. En efecto, "Balzac decía que los solterones reemplazan los sentimientos por hábitos. Igualmente, los profesores reemplazan los descubrimientos por lecciones" (291). O bien enseñar nos convierte en actores que recitamos la misma pieza a veces, o bien se constituye en una marcha hacia lo desconocido mediante el descubrimiento. Obviamente, es esta segunda parte del dilema la que nos interesa asumir por cuanto abre constantemente nuevas perspectivas, y es la que a sus ojos aparece como interesante y con mayor razón si se opta por ver en la ciencia un medio de saber que nunca se termina de aprender.

\section{Obras citadas}

Aristóteles. Metafísica. Gredos, 1994.

Bachelard, Gaston. Essai sur la connaissance approchée. Vrin, 1969.

Bachelard, Gaston. El racionalismo aplicado. Paidós, 1978. 
Bachelard, Gaston. El materialismo racional. Paidós, 1976.

Bachelard, Gaston. El psicoanálisis del fuego. Alianza, 1966.

Bachelard, Gaston. La actividad racionalista de la física contemporánea. Siglo Veinte, 1975.

Bachelard, Gaston. La filosofía del no: ensayo de una filosofía del nuevo espíritu científico. Amorrortu, 1973.

Bachelard, Gaston. La formación del espíritu científico. Siglo Veintiuno, 1987. 



\section{Psicoanálisis y formación de los conceptos ${ }^{22}$}

Uno de los conceptos claves en Gastón Bachelard es, sin duda, el de psicoanálisis, presente a lo largo de su reflexión filosófica de las ciencias y en la poética de lo imaginario. El carácter polémico se puede juzgar a partir de los numerosos trabajos que le han sido consagrados y de las discusiones suscitadas como las que se registran en el Coloquio de Cerisy-la-Salle y más recientemente en la Universidad de Dijon durante las jornadas de noviembre de 1934 con ocasión del centenario de su nacimiento. Ya las mismas expresiones "psicoanálisis del fuego", "psicoanálisis material”, "psicoanálisis cósmico" nos sitúan frente a un psicoanálisis muy especial, el de los objetos, que aplicado al conocimiento científico las toma "no solamente en su imagen y uso sino también en su propia materialidad" (Quillet, Bachelard 18). El mérito de haber colocado la noción de espíritu científico en el centro de las

22 Publicado en Revista de Psicología. Universidad Nacional de Colombia, n. ${ }^{\circ}$ 25, 1985, pp. 21-26. 
reflexiones sobre una actividad que se encuentra siempre contradiciendo al conocimiento común y el intento por explicarla a través de la historia y de quien la produce nos dan la clave del recurso al psicoanálisis. Con él se propone una función básicamente purificadora sobre la cual pueda apoyarse todo espíritu científico en su proceso de constitución.

Lo que es psicoanalizado no es solamente el obstáculo epistemológico tal como aparece en La formación del espíritu científico, sino también los intereses afectivos puestos en el objeto y que pueden ejercer una especie de mutación del conocimiento en admiración y de las ideas en imágenes. Es bien ilustrativo al respecto que la alquimia en su intento de explicar las cosas por medio de imágenes de ninguna manera constituye una etapa inferior a la química, sino más bien un obstáculo. El mercurio es imaginado como agua por su poder de evaporación, como fuego invisible, como espíritu de aire, como alma por su cualidad vital, etc. El oro y la plata son pensados por medio de sus símbolos (círculo y media luna) y las operaciones alquímicas son descritas como cópulas. Toda esta mezcla de imágenes valoradas y de pensamiento simbólico corresponden exactamente a una mentalidad precientífica de la que es inseparable la acción de un psicoanálisis material destinado a curar esas imágenes.

Fuego y tierra son el Times de los elementos iniciales de la construcción del cuerpo del mundo y al mismo tiempo aparecen designados por dos sentidos, la vista (por el fuego el universo es visible) y el tacto (por la tierra el mundo es tangible). La teoría de los elementos soporta una lectura bien interesante que nos permite seguir el desarrollo de la noción de arquetipo. La premisa de que "toda materia imaginada, toda materia meditada, es inmediatamente la imagen de una intimidad" (La tierra y las ensoñaciones del reposo 14) es básica para comprender que la teoría de los elementos reposa en arquetipos o representaciones colectivas que deben ser examinadas por el psicoanálisis material. De esta manera, en la representación platónica de la tierra por medio de una figura geométrica limitada por seis cuadrados, más allá de una justificación racional es preciso encontrar elementos propios de una simbología inconsciente en la cual el cuadrado estaría representando la maternidad de la tierra. "El cuadrado es maternal. El cuadrado es terrestre. Por sí solo, representará la maternidad de la tierra, 
la femineidad fuerte" (El materialismo racional 50), señala Bachelard apoyándose en trabajos de Jung ${ }^{23}$.

Cuando se considera el hecho científico como una producción del espíritu humano se comprende una vez más el interés por explorar el inconsciente y determinar qué fuerzas psíquicas están interviniendo en dicha actividad. Una aclaración en el Psicoanálisis del fuego permite precisar el sentido dado a la noción de psicoanálisis del conocimiento objetivo. Se trata, afirma, de indagar la acción, los valores inconscientes en la base misma del conocimiento empírico científico. Bachelard puede después de Jung afirmar que tiende a descubrir en el inconsciente arquetipos como la cuaternidad y símbolos que son también arquetipos.

Aquí reside precisamente la constante oposición entre valores simbólicos presentes en el inconsciente y valores de la racionalidad. En este sentido, hay una doble inscripción del valor que remite siempre a la tarea de purificar al espíritu científico de la afectividad de las convicciones y de las imágenes rápidas que le ofrece el conocimiento común. El concepto de "alimento", por ejemplo, obstáculo para la aparición de la nueva técnica de alumbrado conocida con el nombre de bombilla eléctrica o invento de Edison. El concepto de "corpúsculo" entendido como cuerpo pequeñito a través de los que nos presenta la intuición del conocimiento común es una simplificación enraizada en el inconsciente con la que tuvo que romper la física contemporánea para poder explicar los electrones, protones, neutrones, etc.

Es en la distinción entre valores de la racionalidad, esto es, los de una actividad en constante reorganización y valores expresados por medio de una cadena de oposiciones (bueno/malo, puro/impuro) donde más se puede apreciar el alcance epistemológico de la ruptura entre conocimiento común y conocimiento científico. El conocimiento común se fundamenta en el utilitarismo y el finalismo y se acompaña de elementales juicios de valor que de ninguna manera van a acelerar el desarrollo del conocimiento mismo. Por eso la noción de fluido, por ejemplo, "en el pensamiento precientífico se carga fácilmente de los más

23 Muchas de las imágenes pintorescas de La formación del espíritu científico, sobre todo las relacionadas con la mentalidad alquímica, la naturaleza doble del mercurio, son tomadas directamente de Carl Jung, en Psicología y alquimia. 
confusos valores: es magnético, es vital, conduce a la vida, conduce a la muerte" (El materialismo racional 119). El invento de la máquina de coser implicó una ruptura con el trabajo a mano de la costurera. Con estos ejemplos se traduce en su sentido exacto la idea constantemente expresada de que "la ciencia no es el pleonasmo de la experiencia" (El racionalismo aplicado 12 ).

El psicoanálisis que profesa Bachelard ${ }^{24}$ es un método para dar cuenta del progreso de las ciencias y de los diversos estados de desarrollo por los que ellas pasan. Si las ciencias son racionalidades progresivas que en su dinámica propia están descalificando el conocimiento común, que tienen un pasado, "un pasado reformado", es preciso poner de manifiesto la fuente de donde brotan las convicciones subjetivas, las imágenes y las representaciones simbólicas en la relación sujeto-objeto. Es esta búsqueda de condiciones psicológicas del progreso científico la que nos hace pensar en una problemática bien paralela a la emprendida por Francis Bacon cuando se propone indagar por las causas del error o, más bien, por las "fuentes psicológicas" del error, en expresión de Cassirer.

Bien se podría establecer una tabla de equivalencias entre los obstáculos y todo aquello que, según el autor del Novum Organon, hacía imposible el conocimiento, en especial los ídolos de la plaza surgidos en el comercio humano a través del lenguaje. El énfasis puesto también en el obstáculo verbal, el abuso con las palabras, las trampas del lenguaje y el conflicto de las significaciones son suficientes para sugerir tanto una actitud de vigilancia como de rechazo de las significaciones del lenguaje común. La palabra no es el concepto, subraya Bachelard, cuando insiste en la necesidad de ir a la formación de los conceptos y hacer evidente la diferencia entre lenguaje común y lenguaje científico. Remontándonos al siglo XVII, y esta es una hipótesis, estamos quizás frente a una reformulación de uno de los conceptos del Método,

24 Es preciso advertir el uso libre de la terminología y la facilidad con la que Bachelard pasa de una expresión a otra dentro de un mismo proyecto. Sin distinguir los términos que constantemente utiliza como equivalentes: "psicología de un inconsciente científico", "psicoanálisis del conocimiento objetivo", "psicoanálisis de la razón", "psicoanálisis cultural”, "psicoanálisis material”, "psicoanálisis cósmico". 
entendido como una propedéutica, una especie de higiene del pensamiento para purificarlo de las ideas falsas, de los prejuicios. Medicina mentis es precisamente el título de la obra de Ehrenfried Walter von Tschirnhaus, uno de los corresponsales de Spinoza, que pone en evidencia preceptos generales para avanzar más fácilmente en el descubrimiento de las verdades. Pero no es en razón de los preceptos de metodología, sino en la confianza común puesta en el futuro del conocimiento objetivo y de la capacidad de la razón frente a los errores y rectificaciones como Bachelard concibió el pensamiento científico en un pasaje conocido del Racionalismo aplicado: "una verdad sobre un fondo de error".

\section{La formación de los conceptos}

Una de las lecciones de la tesis doctoral de 1927, Essai sur la connaissance approchée, es la rectificación incesante del pensamiento ante lo real. La idea misma de que el conocimiento es un movimiento inacabado, es creación continua, es evolución del espíritu, constituye el trasfondo de la noción de ciencia como producción, como creadora de realidad (La actividad racionalista de la física contemporánea). Ahora bien, si la ciencia ya no es una elección de cosas esto implica que lo real ya no pueda concebirse como lo inmediatamente dado y represente para la actividad científica solamente un "simple pretexto y ya no un objeto de conocimiento" (El nuevo espíritu científico). En este sentido, se rompe con el concepto de lo real como algo existente fuera del pensamiento, para definirlo más bien en relación con la razón.

La formación histórica de los conceptos es una de las contribuciones fundamentales de Bachelard a una tendencia actual de la epistemología que insiste más sobre la historia de las ciencias que sobre su lógica. El estudio de los conceptos de "capacidad eléctrica”, de "masa”, comprometen una vez más al psicoanálisis en la tarea de determinar las condiciones de formación de un concepto desde su aparición, los primeros sentidos, las etapas de madurez y las cargas afectivas. Tarea de dialectizar un concepto, como algunas veces la denomina. En La filosofía del no se puede seguir en detalle la formación del concepto de masa en sus diferentes niveles, desde el realismo ingenuo hasta 
el racionalismo discursivo. El recorrido tiende a mostrar que en una perspectiva histórica el progreso científico del concepto va apareciendo de un nivel a otro a través de una separación cada vez mayor del conocimiento común.

Si nos detenemos en la obra complementaria de la tesis doctoral Etude sur l'évolution d'un problème de physique, la práctica de la formación de los conceptos se centra en el concepto de lo calórico desde el siglo XVII hasta Boussinesq; el calor como energía, etc. Y es esa referencia al pluralismo de los sentidos la que nos da a comprender la necesidad de mirar el problema de las significaciones de los términos, de los conceptos en el lenguaje científico. Problema semántico, en el fondo, que separa de partida las significaciones usuales, ordinarias, de las significaciones científicas.

La exploración en la formación de los conceptos de una disciplina va a encontrar eco en los trabajos de Foucault y sobre todo de Canguilhem. Por ejemplo, en el campo de las investigaciones de Foucault sobre la locura, este concepto aparece con sus variaciones en el tiempo desde la época clásica (cuando todavía no es enfermedad) hasta cuando se convierte en objeto del saber de la psiquiatría. Por otra parte, y en una filiación bachelardiana quizás más directa Georges Canguilhem aplica el método de la formación de los conceptos a las ciencias biológicas. Trabajar un concepto en su extensión y comprensión ayuda a comprender el pasado de una ciencia, si bien, como él mismo lo señala, no se puede confundir el pasado de una ciencia de hoy con la misma ciencia en su pasado (Ideología y racionalidad). Con la estricta observación del método para separar el objeto de las ataduras, de las subdeterminaciones afectivas y de las intuiciones del sentido común Canguilhem lo aplica a las ciencias biológicas en El conocimiento de la vida: desde Hooke hasta Schwan considerado como el fundador de la teoría celular, pasando por los trabajos de Malpighi, el botánico Yon Mohl, y Dujardn. Es importante destacar que era Hooke quien inventa el concepto después de practicar un corte en un corcho. Y es él mismo quien inventa el término por asimilación del objeto vegetal con un panal de miel y este a su vez con una habitación. Con el ejemplo de la célula, señala Canguilhem, "estamos en presencia de un objeto biológico en el que la subdeterminación afectiva es incontestable y considerable. 
El psicoanálisis del conocimiento cuenta de ahora en adelante con bastantes y felices resultados" (El conocimiento de la vida 53). La formación del concepto de reflejo, la formación del concepto de regulación biológica supone no solamente que para Canguilhem las teorías no nacen de los hechos, sino también que en la orientación bachelardiana "únicamente el concepto es el objeto de la Historia de las ciencias" (M. Fichant).

\section{Obras citadas}

Bachelard, Gaston. La tierra y las ensoñaciones del reposo. Fondo de Cultura Económica, 2006.

Bachelard, Gaston. El materialismo racional. Paidós, 1976.

Bachelard, Gaston. Étude sur l'évolution d'un problème de physique. La propagation thermique dans les solides. Vrin, 1927.

Bachelard, Gaston. El nuevo espíritu científico. Nueva Imagen, 1985.

Bachelard, Gaston. La actividad racionalista de la física contemporánea. Siglo Veinte, 1975.

Canguilhem, George. El conocimiento de la vida. Anagrama, 1976.

Canguilhem, George. La formation du concept de réflexe aux XVII et XVIIII siècles. Vrin, 1994.

Canguilhem, George. Ideología y racionalidad en la historia de las ciencias de la vida: nuevos estudios de historia y de filosofía de las ciencias. Amorrortu, 2005. Jung, Carl. Psicología y alquimia. Obra completa, XII. Trotta, 2005.

Quillet, Jean-Pierre. Bachelard. Seghers, 1964.

Tschirnhaus, Ehrenfried Walter. Medicina mentis. Guida, 1987. 



\section{Piaget y la filosofía ${ }^{25}$}

Además de biólogo, sicólogo y creador de la epistemología genética, Jean Piaget mantuvo desde muy temprano una relación decidida con la filosofía, indispensable para el estudio crítico del conocimiento científico y sobre todo para el científico interesado en la explicación biológica del conocimiento. Es justamente ahí, en la conjunción de una experiencia personal con la filosofía donde buscará precisar las relaciones entre las ciencias y la filosofía. Que la filosofía no logra alcanzar conocimiento, en oposición a la tradición sino más bien conduce a una sabiduría será una tesis central. En segundo lugar, es importante observar que la ciencia se caracteriza por el progreso, se encuentra en constante progreso, en cambio la filosofía no posee instrumentos de verificación que permitan plantearlo como en las ciencias. En esta perspectiva, es claro que el carácter propio del conocimiento científico es la objetividad concebida mediante métodos deductivos (lógico-matemáticos) o experimentales

25 Ponencia presentada en el Congreso Internacional en homenaje a Jean Piaget celebrado por la Universidad Libre en mayo de 2010. Publicada posteriormente en Sin Fundamento: Revista colombiana de filosofía, No.12, septiembre de 2009, pp. 83-89. 
adecuados al objeto y al acuerdo entre sujetos “epistémicos” dentro de un determinado campo del conocimiento.

Podríamos definir la epistemología en una primera aproximación como el estudio de la constitución de conocimientos válidos (Logique et connaissance scientifique 6) y la filosofía como una toma de posición razonada con respecto a la totalidad de lo real (Sabiduría e ilusiones de la filosofía 51). "Razonado" o toma de posición razonada es lo opuesto a creencias admitidas sin elaboración reflexiva, rápidamente tomas de posiciones afectivas. Y la lógica como el estudio de las condiciones de verdad. ¿Pero por qué se consideró la filosofía como un conocimiento en Occidente? La razón no es otra que porque "fue durante mucho tiempo solidaria de la ciencia hasta tal punto que la distinción entre sociedad y filosofía no existía para los primeros pensadores griegos” (56). Cuando los primeros filósofos griegos empezaron a pensar lo real con la razón y no con el lenguaje del mito, sus concepciones del mundo participaron a la vez de la filosofía y de la ciencia en Mileto. Valga mencionar el enriquecimiento de la filosofía a través de los descubrimientos científicos particulares: el nacimiento del platonismo con la reflexión matemática, el aristotelismo con el descubrimiento de la clasificación biológica, el cartesianismo como aplicación del álgebra a la geometría, el kantismo y la ciencia newtoniana, etc.

A partir de esta distinción establece las tres grandes teorías del conocimiento clasificadas en metacientíficas, paracientíficas y científicas.

Las metacientíficas parten de una reflexión sobre las ciencias con tendencia a prolongarla dentro de una teoría general del conocimiento. Ejemplos: Platón y las matemáticas, Aristóteles y la lógica, mientras que, en Descartes, Leibniz, Kant, surgen epistemologías mediante la colaboración de las matemáticas con la experiencia física. Un sistema filosófico, por el contrario, por la tendencia a traducir la totalidad de la experiencia vivida es más rico en aspectos propios del "sujeto individual” en su relación con la sociedad y el entorno, contiene juicios de valor que ponen en riesgo la objetividad y la posibilidad de acuerdos.

Las paracientíficas son las que se apoyan en una crítica de las ciencias para fundamentar un modo de conocimiento científico y opuesto a este. Por ejemplo, podemos encontrar en la época contemporánea 
filosofías que postulan la existencia de modos de conocimiento propiamente filosóficos, independientes del conocimiento científico, fundamentados en los límites de la ciencia y de la razón, abiertos incluso a lo irracional y simbólico. En el terreno de la epistemología bergsoniana el análisis muestra que esta reposa en la idea central de la ciencia "cada vez menos objetiva y más simbólica en la medida que va de los físico a lo psíquico, pasando por lo vital” (Épistémologie des sciences de l'homme 36).

Las científicas son las que permanecen dentro de una reflexión sobre las ciencias. Su objetivo es explicar el conocimiento científico y no apuntan al conocimiento en general. Abarcan el positivismo lógico y la filosofía de las ciencias del siglo xIX, particularmente en Francia: Comte y las corrientes positivistas, A. Cournot, León Brunschvicg con el profundo estudio Las etapas de la filosofía matemática, de gran importancia para las tesis fundamentales de Bachelard, Koyré (formado en matemática), E. Meyerson (autor de Identidad y realidad), A. Lautman y Jean Cavaillés.

Ahora bien, conviene retener de las tres formas de epistemología un dominio común en el que se puede constatar esa relación orgánica entre los grandes nombres de la historia de la filosofía y los grandes nombres de la historia de la ciencia o de la filosofía de las ciencias. Es por una razón muy clara, expresa el autor, porque "la fuente más fecunda de la reflexión filosófica es la epistemología, y las únicas renovaciones posibles de ésta se deben a la reflexión sobre las ciencias”.

De ahí que la tesis que parece imponerse y que se proclama desde el inicio de Sabiduría e ilusiones de la filosofía: la filosofía tiene el estatuto de sabiduría, pero no el de un saber "provisto de las garantías y de la forma de control que caracterizan lo que se llama conocimiento" (5). La "ilusión” de la filosofía está precisamente ahí en "creer que se basta por sí misma sin comportar ninguna verificación”. Para poder hablar de conocimiento en el verdadero sentido del término son imprescindibles el control y la verificación de los hechos, precisa más tarde en una entrevista con Jean-Claude Bringuier.

La epistemología es una ciencia cercana a las exigencias de rigor, a los procedimientos de verificación experimental y se interesa por las condiciones del pensamiento válido. De esta manera, es definida 
en naturaleza y métodos de la epistemología (17), en una primera aproximación, como el estudio de la constitución de los conocimientos válidos. El término "constitución" comprende, a la vez, las condiciones de accesión y las condiciones propiamente constitutivas, lo que se reúne bajo la expresión "problema epistemológico": ¿cómo son posibles las ciencias? La accesión hace referencia al conocimiento como un proceso en su dimensión histórica; las condiciones constitutivas son las condiciones de carácter formal o experimental y los aportes del objeto a los del sujeto en el proceso de estructuración de los conocimientos. La filosofía puede, sin duda alguna, llegar a la coordinación razonada de valores, pero sigue siendo una sabiduría y no un conocimiento.

Preguntándose ¿cómo son posibles las ciencias?, llega inmediatamente a abordar la validez de los conocimientos en su pluralidad ya que no hay, para Piaget, un conocimiento en general ni un conocimiento científico a secas, sino múltiples formas. La validez de los conocimientos comporta dos componentes: lo normativo y lo constatativo, el componente son las normas, las reglas de las proposiciones en el terreno de la lógica y de las matemáticas; las verdades normativas no se pueden alcanzar por la experimentación, son independientes de la voluntad y de las creencias del individuo.

Ahora bien, desde que se coloca delante de la lógica la idea de validez y si asumimos contra la tradición que la "lógica ya no pertenece a la filosofía" (Sabiduría e ilusiones de la filosofía 21), se deriva la consecuencia central para la epistemología piagetiana fundada sobre la biología, una especie de ruptura con la tradición filosófica que consideraba a la lógica y a la epistemología como partes de la filosofía. Aún más, si tenemos en cuenta que la lógica, insistentemente nos lo recuerda, es en la actualidad "una disciplina autónoma, íntegramente independiente de la metafísica y presenta los caracteres de una ciencia propiamente dicha, con los mismos títulos que las matemáticas" (Sabiduría e ilusiones 20) a partir del siglo XIx, particularmente con el descubrimiento de Boole y el álgebra de la lógica, la lógica anti-formalista de Stuart Mill, la lógica de Herbart y la constitución de la lógica moderna con Frege, Whitehead y Russell. Por otra parte, correlativamente con el empleo de algoritmos se encadena circularmente otra "ilusión fundamental". Es la creencia en que la verdad se puede 
obtener "por simple reflexión sin salir del gabinete de trabajo o de la biblioteca". Al contrario, se obtiene por la deducción, por algoritmos bien precisos o por la experiencia controlada.

Desde la perspectiva anterior, Piaget incursiona luego en la teoría del conocimiento y las creencias de algunas filosofías de poseer el conocimiento, para entrar a examinar sus nexos con la metafísica interrogándose si, por el contrario, presenta tendencias a la autonomía, como ha sucedido con la lógica.

"No hay para las ciencias un conocimiento en general... existen múltiples formas de conocimiento de las que cada una plantea un indefinido número de cuestiones particulares" (Sabiduría e ilusiones 12). Afirmación que ya hemos encontrado y se puede explicar históricamente porque no existía para los primeros filósofos la distinción entre ciencia y filosofía y por esto Occidente concibió la filosofía como un conocimiento que era solidario con el de la ciencia y ha habido evidentemente filósofos que han hecho ciencia. En esta perspectiva, enfatiza el creador de la epistemología genética, los grandes sistemas filosóficos "han nacido de una reflexión sobre los descubrimientos científicos de los mismos autores o sobre una revolución científica propia de la época anterior”. Valga mencionar el nexo evidente de Platón con las matemáticas, Aristóteles con la lógica y la biología, Descartes con el álgebra y la geometría analítica, Leibniz y el cálculo infinitesimal, las anticipaciones de Locke y Hume para la psicología, la relación Kant-Newton, Hegel y Marx en relación con la ciencia de la historia.

Pero es muy claro en el autor mismo el reproche que le hace a la filosofía de creer alcanzar conocimientos, pues el conocimiento presupone sucesivamente la verificación y esta a la vez la delimitación de los problemas. Es así como el Postfacio a la segunda edición de Sabiduría e ilusiones de la filosofía manifiesta el malestar por "tantos filósofos que se dan el derecho de hablar de todo sin método de verificación y presentan el producto de su reflexión como un conocimiento e incluso como una forma superior de saber" (Sabiduría e ilusiones 287).

Entonces, ¿qué es filosofía?

La Filosofía es una toma de posición razonada con respecto a la totalidad de lo real. E inmediatamente entra a analizar el término "razonada" para diferenciarlo de otras tomas de posición puramente prácticas 
o afectivas, y también de las creencias simplemente admitidas sin una reflexión. La totalidad de lo real comprende el conjunto de actividades superiores del hombre como la moral, la estética, la fe religiosa, y no exclusivamente el conocimiento. La meta de la filosofía se extiende entonces a la coordinación de la totalidad de los sistemas de valores, en cambio la ciencia se limita a la coordinación de los valores cognitivos de verdades empírico-deductivas. Esa coordinación razonada por parte de la filosofía es una sabiduría que supone un compromiso y no un conocimiento, porque la visión que resulta de ahí no se puede demostrar por medio de la lógica ni menos comprobar experimentalmente porque carece de instrumentos de verificación. En la conclusión se precisa la forma y función de la filosofía como sabiduría. "Esta síntesis razonada entre las ciencias, cualesquiera que sean, y las condiciones del saber, es lo que hemos llamado una sabiduría, y tal nos parece que es el objeto de la filosofía" (Sabiduría e ilusiones 231).

El progreso cognitivo que caracteriza a toda ciencia y es constante lleva a negárselo a la filosofía, con apoyo en Jaspers, y a radicalizar aún más la oposición entre ciencia y filosofía. Lo cual se vuelve problemático para la filosofía misma y desconcertante para la experiencia de la reflexión. Que Karl Jaspers enseñe que la "filosofía no progresa, contrariamente a las ciencias" implica definir la filosofía desde las ciencias como el fundamento necesario para la explicación del mundo objetivo y por ende como la primera etapa de la filosofía. Detengámonos sin embargo en algunos aspectos comparativos de Jaspers antes de su definición de filosofía como "la búsqueda de la verdad, no la posesión de ella... sus preguntas son más esenciales que sus respuestas, y toda respuesta se convierte en una nueva pregunta".

Las ciencias logran conocimientos ciertos y universalmente aceptados, la filosofía no.

Las ciencias tienen procesos progresivos, la filosofía no.

Después de estas insuficiencias frente a las ciencias, Jaspers aboga por ese "ir de camino buscando", tan necesario e indispensable al hombre, porque sea accesible a todo el mundo y se muestre original en todo momento. Las preguntas de los niños, la "rica filosofía de los niños", ejemplifican con mucha insistencia el sentido del filosofar original. 
Piaget concibió la epistemología genética como una ciencia que se propone remontarse a las fuentes, por consiguiente, a la génesis misma de los conocimientos. "Es el estudio de los mecanismos de evolución (crecimiento) de los conocimientos" y desde una particularidad muy especial, a saber, "el estudio de los estadios sucesivos de una ciencia en función de su desarrollo" (Introduction à l'épistémologie génétique 113-14). El estudio del crecimiento o aumento (el paso de un estado de menor a mayor conocimiento) comprende también el de la formación y desarrollo de los conocimientos y el análisis histórico de los conceptos científicos. El conocimiento científico es dinámico, no estático. La lectura de La evolución creadora (1941) de Henri Bergson además del "flechazo" que le produjo en el proceso de formación filosófica de Piaget mismo no deja dudas sobre los ecos en su concepción del conocimiento como un proceso de construcción continua, activo, en perpetua evolución.

Como psicólogo le otorgó un lugar especial al estudio del pensamiento infantil. En esta dirección se orientan los primeros trabajos sobre el lenguaje y el pensamiento en el niño, el juicio y el razonamiento en el niño, la representación del mundo en el niño, el juicio moral, la formación del símbolo en el niño, las nociones de movimiento y de velocidad. Conocer un objeto es para Piaget actuar sobre el objeto. El conocimiento físico (perteneciente a los objetos del mundo natural) lo adquiere el niño por medio de la manipulación de los objetos que le rodean, en interacción con ellos, ya sea la dureza de un cuerpo, su peso, el sonido que produce, el sabor, etc. El conocimiento no es un estado, sino un proceso activo, dialéctico por la constante reorganización. Valga recordar la bachelardiana idea del conocimiento inacabado, que el conocimiento es movimiento, no es un "acto pleno". En síntesis, podemos comprender mejor el conocimiento si comprendemos sus procesos de adquisición. La definición de mentira en el niño se puede seguir en las siguientes etapas: una mentira es "una mala palabra" (hasta 6 años), "mentira es una cosa que no es verdad" (6 o 7-10 años), "es mentirosa toda afirmación intencionalmente falsa" (10-11 años).

En relación con la lógica conviene retener la importancia que le otorga en la construcción del pensamiento científico como disciplina 
autónoma e independiente de la metafísica, con características que la asimilan a una ciencia a tal punto que justifica su tendencia separatista con respecto a la filosofía.

Queda una cuestión en suspenso y es la exigencia de progreso que le hace a la filosofía y más directamente a la metafísica. En efecto, ¿qué podemos pensar de una afirmación como esta: "la metafísica no ha hecho ningún progreso desde Platón a Heidegger”. Es este el interrogante que nos lleva al corazón de una crítica al sistema piagetiano en su reducción del conocimiento filosófico al científico, ya que introduce en el acto mismo de concebir la filosofía exigencias de control deductivo (lógico-matemático) o experimental propias del conocimiento científico en el establecimiento de las verdades. De ahí que considere una deshonestidad intelectual "afirmar lo que sea en un terreno tocante a ciertos hechos, sin un control metodológico comprobable para cada uno de ellos, o bien en los terrenos formales cuando se carece de un control lógico" (Sabiduría e ilusiones 21).

Por otra parte, entre filosofía y ciencia hay una diferencia de objeto ya señalada. Si bien no posee un objeto preciso, la filosofía entendida como "una toma de posición razonada con respecto a la totalidad de lo real" comprende un conjunto de actividades correspondiente a esa totalidad y coordina los sistemas de valores morales, estéticos, religiosos, elaborados por el hombre con una visión del mundo. La ciencia coordina valores cognitivos de la verdad empírico-deductiva que se imponen con la ayuda de los métodos.

En síntesis, la filosofía es para Piaget una sabiduría, ese es su objeto, por cuanto implica una toma de posición vital, reitera en la conclusión reafirmando su nexo con Jaspers, quien explica el origen de la filosofía en el asombro, la duda, en la experiencia de las situaciones límites que le muestran al hombre su finitud (la muerte, el ocaso, el fracaso) y en la voluntad de comunicación. Es para todos, es necesaria para cada individuo, y en relación con las investigaciones científicas estas "crean una situación para la filosofía” en cada época. La filosofía "al menos enseña a no dejarse engañar”, enfatiza en el XIII, tema de la Iniciación al método filosófico (182). 


\section{Obras citadas}

Battro, M. Antonio. El pensamiento de Jean Piaget. Emecé editores, 1963.

Bergson, Henri. La evolución creadora. Cactus, 2012.

Brunschvicg, Leon. Las etapas de la filosofía matemática. Lautaro, 1965.

Meyerson, Emilio. Identidad y realidad. Reus, 1929.

Cellerier, Guy. Piaget. Presses Universitaires de France, 1973.

Jaspers, Karl. La filosofía desde el punto de vista de la existencia. Fondo de Cultura Económica, 1953.

Jaspers, Karl. Iniciación al método filosófico. Espasa-Calpe, 1977.

Jaspers, Karl. Iniciación al método filosófico. Espasa-Calpe, 1977.

Piaget, Jean. Sabiduría e ilusiones de la filosofía. Península, 1973.

Jaspers, Karl. Épistémologie des sciences de l'homme. Gallimard, 1970.

Jaspers, Karl. Lógica y conocimiento científico. Proteo, 1970.

Jaspers, Karl. Introduction à l'épistémologie génétique. Presses Universitaires de France, 1950.

Jaspers, Karl. Naturaleza y métodos de la epistemología. Proteo, 1970. 
